\title{
Noodtoestanden in het Nederlandse publiekrecht
}

Jan-Peter Loof ${ }^{\star}$

\section{Inleiding: probleemstelling en hedendaagse context}

\section{I.I 'Nood breekt wet' als algemeen rechtsverschijnsel}

Bijna alle nationale rechtssystemen voorzien in een mogelijkheid voor de overheid om in buitengewone omstandigheden een noodtoestand of een andere uitzonderingstoestand uit te roepen en maatregelen te treffen die afwijken van het 'normale' rechtsstelsel. De regels die hierop betrekking hebben, worden doorgaans aangeduid met de term 'staatsnoodrecht'. Een groot aantal staten kent, als onderdeel van dit staatsnoodrecht, constitutionele bepalingen die het in tijden van oorlog of andere noodsituaties die de staatsveiligheid ernstig bedreigen mogelijk maken dat bepaalde rechten en vrijheden van individuen niet alleen worden beperkt, maar dat verdergaand wordt afgeweken van de bescherming van deze rechten. ${ }^{\mathrm{I}}$ Men spreekt in dat verband wel van het 'opschorten' van de betreffende mensenrechten.

Nederland vormt hierop geen uitzondering: artikel I03 Grondwet reguleert het uitroepen van een 'uitzonderingstoestand' en de juridische consequenties daarvan. Blijkens dit artikel kan tijdens zo'n uitzonderingstoestand worden afgeweken van bepaalde grondrechten. Daarnaast kan in crisissituaties ook buiten het formeel uitroepen van een noodtoestand om gebruik worden gemaakt van diverse noodbevoegdheden en is er een praktijk waarin op gemeentelijk niveau met enige regelmaat noodbevoegdheden worden toegepast door de burgemeester.

\section{I.2 Probleemstelling}

In dit preadvies staat de vormgeving van het recht inzake noodtoestanden in het Nederlandse publiekrecht centraal. Het Nederlandse constitutionele recht kent zowel in de Grondwet als in diverse organieke en andere wetten bepalingen met

\footnotetext{
* Mr. dr. J.P. Loof is waarnemend ondervoorzitter onderzoek, advies en communicatie van het College voor de Rechten van de Mens en doceert staatsrecht en mensenrechten aan de faculteit der rechtsgeleerdheid van de Universiteit Leiden. Dit preadvies is in aanzienlijke mate gebaseerd op zijn proefschrift Mensenrechten en staatsveiligheid: verenigbare grootheden? Opschorting en beperking van mensenrechtenbescherming tijdens noodtoestanden en andere situaties die de staatsveiligheid bedreigen (diss. Leiden), Nijmegen: WLP 2005. Uiteraard wel met de nodige actualisering.

I C.J. Friedrich, Constitutional Government and Democracy. Theory and Practice in Europe and America, Waltham-Toronto-London: Blaisdell 1968 ( $4^{\text {th }}$ ed.), p. $55^{8}$. Zie specifiek over dit onderdeel van het staatsnoodrecht tevens het preadvies van Duynstee voor deze vereniging uit I950: W.J.A.J. Duynstee, 'Vrijheidsrechten in noodtoestanden', Preadviezen voor de Ver. voor vergelijkende studie van het recht in België en Nederland, Zwolle: W.E.J. Tjeenk Willink I950, p. 73-I38.
} 
betrekking tot het uitroepen van een noodtoestand of het gebruikmaken van noodbevoegdheden, zowel op nationaal als op gemeentelijk niveau. Uiteraard zullen deze bepalingen in het hierna volgende nader in kaart worden gebracht en zal worden besproken hoe het uitroepen van een noodtoestand en de inwerkingtreding daarvan is geregeld. Eveneens zal worden bezien wat de juridische consequenties van inwerkingtreding van een noodtoestand of gebruikmaking van noodbevoegdheden zijn en op welke wijze er controle wordt uitgeoefend door parlement en/of rechter op de uitoefening van noodbevoegdheden en het tot stand brengen van noodbesluiten. Die wijze van parlementaire en rechterlijke controle kan overigens alleen worden begrepen na kennisname van de discussies die zich in het verleden, met name kort na de Tweede Wereldoorlog hierover hebben voorgedaan.

Bij dit alles is de focus gericht op de vraag in welke mate afwijking van grondrechten tijdens een noodtoestand is toegestaan. Voor het antwoord op die vraag zal overigens niet louter naar het Nederlandse staatsrecht worden gekeken, maar ook naar enkele belangrijke bepalingen uit het Europees verdrag inzake de rechten van de mens en de fundamentele vrijheden (EVRM) en het Internationaal verdrag inzake burgerrechten en politieke rechten (IVBPR).

De centrale vraag voor dit preadvies ligt in het verlengde van het wettelijk geregelde (staats)noodrecht en betreft de toereikendheid ervan in het licht van de hedendaagse bedreigingen van de (staats)veiligheid en de crisissituaties die als gevolg daarvan kunnen optreden. Is er vanuit het perspectief van deze hedendaagse crisissituaties behoefte aan een ander type nood- of uitzonderingstoestand en hoe zou die er dan uit moeten zien? Het laatste deel van deze vraag moet zo worden begrepen dat het erom gaat te inventariseren (a) aan wat voor type van het normale rechtsstelsel afwijkende bevoegdheden vandaag de dag dan behoefte is, (b) of dit dan bevoegdheden zijn die een afwijking van grondrechten met zich brengen en (c) welke ruimte de genoemde mensenrechtenverdragen daarvoor laten.

\section{I.3 Hedendaagse context: transnationale terreurdreiging}

De constitutioneelrechtelijke bepalingen over noodtoestanden en noodbevoegdheden vinden in veel landen hun oorsprong in de behoefte om externe of interne bedreigingen van de territoriale integriteit en van het functioneren van het staatsbestel het hoofd te kunnen bieden: een aanval door een buitenlandse mogendheid op het grondgebied, grootschalige binnenlandse oproer, geweldpleging door afscheidingsbewegingen, enzovoort. Daarbij gaat het dan vaak om het creëren van (nood)bevoegdheden die zien op situaties waarin zich reeds daadwerkelijk inbreuken op het functioneren van de rechtsorde c.q. het staatsbestel dan wel grootschalige wanordelijkheden voordoen of waarin die op korte termijn aanstaande zijn.

In het post 9/11-tijdperk is duidelijk geworden dat de dreiging van transnationaal terrorisme in vele landen aanzienlijk is. Volgens de Nationaal Coördinator Terrorisme en Veiligheid (NCTV) is het terreurdreigingsniveau in Nederland al enige jaren 'substantieel'. Dat is het op een na hoogste niveau en betekent (a) dat de kans dat een aanslag in Nederland zal plaatsvinden reëel is, o.m. omdat aanslagen plaatsvinden in andere, met Nederland vergelijkbare, landen en (b) dat Nederland door terroristische netwerken wordt gezien als mogelijk doelwit, maar dat er geen concrete aanwijzingen zijn dat er voorbereidingen worden getroffen 
om in Nederland een aanslag te plegen. ${ }^{2}$ In sommige Europese landen is in recente jaren in reactie op terroristische aanslagen een noodtoestand uitgeroepen: het Verenigd Koninkrijk (200I en sindsdien herhaaldelijk verlengd) en Frankrijk (20I5, ook reeds enkele malen verlengd).

$\mathrm{Nu}$ kan, naast het plegen van een terreuraanslag, ook de dreiging van terroristische aanslagen worden beschouwd als een aantasting van de nationale veiligheid, maar deze is naar haar aard minder 'grijpbaar' in die zin dat het moment waarop zich daadwerkelijk een aanslag zal voordoen zich niet of nauwelijks laat voorspellen. Dat doet de vraag rijzen of de juridische vormgeving van overheidsoptreden dat gericht is op de voorbereiding van de reactie van de autoriteiten op een daadwerkelijke aanslag of - liever nog - op het voorkomen van zo'n aanslag zich makkelijk laat vertalen in termen van noodtoestanden of (tijdelijke) noodbevoegdheden. ${ }^{3}$ De terreurdreiging kan zich immers jaren op een min of meer substantieel niveau bevinden.

Op staten rust de verplichting om alle maatregelen te treffen die noodzakelijk zijn om de fundamentele rechten van burgers, in het bijzonder hun recht op leven, te beschermen tegen terroristische misdrijven. ${ }^{4}$ Zo stelt artikel I van de Raad van Europa Guidelines on human rights and the fight against terrorism:5 'States are under the obligation to take the measures needed to protect the fundamental rights of everyone within their jurisdiction against terrorist acts, especially the right to life. This positive obligation fully justifies States' fight against terrorism in accordance with the present guidelines.' De strijd tegen terrorisme en de bescherming van de staatsveiligheid die aanleiding kunnen zijn voor maatregelen die een aantasting betekenen van de bescherming van bepaalde grondrechten, kunnen op zich dus ook weer een basis vinden in de bescherming van andere grondrechten. Tegelijkertijd benadrukken zowel bovengenoemde guidelines als diverse rapporten die in VN-verband zijn opgesteld, onder meer door de Special Rapporteur on Terrorism and Human Rights, de latere Special Rapporteur on the promotion and protection of human rights and fundamental freedoms while countering terrorism en de VN-Hoge Commissaris voor de Mensenrechten, dat de strijd tegen terrorisme en het grijpen naar noodbevoegdheden als onderdeel daarvan geen rechtvaardiging kunnen vormen voor een schending van mensenrechtennormen. ${ }^{6}$

In de laatste decennia is de context van terreurdreiging wel grotendeels bepalend voor de benadering van juridische vraagstukken rondom noodtoestanden, zeker waar het gaat om noodtoestanden die afwijking van de normale mensen-

2 Bron: https://www.nctv.nl/organisatie/ct/dtn/Opbouw-dreigingsniveaus-DTN/index.aspx, geraadpleegd op 28 augustus 2016.

3 Zie hierover reeds het advies van de Raad voor het Openbaar Bestuur, Tussen oorlog en vrede. Kader voor een balans tussen vrijheidsrechten en veiligheid, Den Haag: oktober 2005.

4 Relevant is hier o.m. de zogenoemde 'Osman-doctrine' in de rechtspraak van het EHRM (EHRM 28 oktober I998, nr. 87/I997/87I/Io83 (Osman/VK)). Zie o.m. R.W. van Zuijlen, Veiligheid als opdracht. Een onderzoek naar veiligheid als fundamenteel recht en als positieve verplichting van de staat in het licht van de politietaak tot strafrechtelijke rechtshandhaving (diss. EUR), Nijmegen: WLP 2008, i.h.b. hoofdstuk VI; U. Rosenthal \& E.R. Muller, 'Het grondrecht op veiligheid', in: E.R. Muller (red.), Veiligheid. Studies over inhoud, organisatie en maatregelen, Alphen aan den Rijn: Kluwer 2004, p. 5970.

5 Council of Europe, Directorate General of Human Rights, Guidelines on human rights and the fight against terrorism (adopted by the Committee of Ministers on II July 2002 at the 804th meeting of the Ministers' Deputies), December 2002.

6 Zie o.m. VN Doc. E.CN.4/2002/I8, § 5 en VN Doc. A/HRC/3I/65 (22 februari 20I6), § I6. 
rechtenbescherming met zich brengen. En sinds 2008 kan daarnaast gewezen worden op de context van de bankencrisis. Ook bij de overheidsinterventies ter bestrijding daarvan kan sprake zijn van een inbreuk op fundamentele rechten, denk aan de eigendomsrechten van aandeelhouders van een bank die omwille van de stabiliteit van het financieel systeem genationaliseerd wordt, en van een beperken of omzeilen van diverse parlementaire rechten. ${ }^{7}$ En juist die context maakt dat de hierboven geformuleerde centrale vraag van dit preadvies een relevante is. Sluit het staatsnoodrecht nog aan bij de hedendaagse veiligheidsbedreigingen? De actualiteitswaarde van deze vraag wordt onderstreept door het feit dat het kabinet in maart 2016 aankondigde te starten 'met een verkenning waarin wordt bezien of het staatsnoodrecht, als de toepassing daarvan noodzakelijk zou zijn gezien de dreiging die uitgaat van het jihadisme, voldoende is toegerust op de dan aan de orde zijnde situatie'. ${ }^{8}$

\section{$2 \quad$ Noodtoestand en staatsnoodrecht: een nadere (begrips)verkenning en analyse}

\section{I Begrippen: objectief en subjectief staatsnoodrecht}

In het algemeen maakt men in de Nederlandse staatsrechtelijke literatuur onderscheid tussen subjectief en objectief staatsnoodrecht. Het subjectief staatsnoodrecht is het - ongeschreven en in beginsel onbeperkte - recht van de overheid om, wanneer de staat in een noodsituatie is geraakt, zo nodig tegen het geschreven recht in te handelen..$^{9}$ Objectief staatsnoodrecht omvat: ${ }^{\text {10 }}$

a) wetgeving die bepalingen bevat ten aanzien van de bevoegdheden, uit te oefenen in tijden van staatsnood: het tevoren geschreven recht, bedoeld om te gelden in de onder dat recht voorziene omstandigheden;

b) regelingen en besluiten die tijdens een uitzonderingstoestand tot stand komen en stoelen op de vooraf tot stand gebrachte noodwetgeving;

c) regelingen en besluiten die tijdens een uitzonderingstoestand tot stand komen en die stoelen op het subjectieve staatsnoodrecht.

7 Zie hierover: S. Daniëls, 'De staatsnoodrechtelijke hiaten van de Interventiewet', NJB 20I2/I467; P.C. Adriaanse, T. Barkhuysen \& M.L. van Emmerik, 'Staatssteun en kredietcrisis Staats(steun) rechtelijk noodrecht gewenst?', NJB 2008/2053.

8 Kamerstukken II 20I5/I6, 29754 , nr. 363, p. 7.

9 M.I. Prins, Staatsnoodrecht (diss. Amsterdam), Amsterdam: Cohen IgII, p. 2I en 46-47. Aldus J.A. Eigeman, 'De staatsrechtelijke betekenis van onze oorlogswet', Rechtsgeleerd Magazijn Themis I9I8, p. 25-68; A.A.L.F. van Dullemen, Staatsnoodrecht en rechtsstaat, Alphen aan den Rijn: Samson I946, p. 4; C.W. van der Pot, 'Openingrede $72^{\text {ste }}$ vergadering NJV', NJB I946, p. 442; G. Russel, De Londense Koninklijke Besluiten in het licht van Staatsnoodrecht, Haarlem: H.D. Tjeenk Willink I948, p. II; G. van den Bergh, 'Staatsnoodrecht en toetsingsrecht', in: Verzamelde staatsrechtelijke opstellen, Alphen aan den Rijn: Samson I949, p. 26; J.R. Stellinga, Grondtrekken van het Nederlands Staatsrecht, Zwolle: W.E.J. Tjeenk Willink 1953, p. 473. In dezelfde zin o.m. M.J.J. van den Honert \& P. de Rijk, 'Uitzonderingstoestanden onder de nieuwe Grondwet', Nederlands Juristenblad I982, p. 869; Th.J. Clarenbeek, De Oorlogswet voor Nederland (diss. Amsterdam), Alphen aan den Rijn: Samson I978, p. 6.

Io Clarenbeek I978, p. 8; C.A.J.M. Kortmann, 'Iets over Staatsnoodrecht', Militair Rechtelijk Tijdschrift I984, p. I83-I84; Van den Honert \& De Rijk I982, p. 869. 
Met Kummeling kan worden ingestemd dat het helderder is om gewoon van geschreven en ongeschreven staatsnoodrecht te spreken. ${ }^{\text {II }}$ Kummeling is daarbij zelfs geneigd om kortweg van noodrecht te spreken in plaats van staatsnoodrecht, omdat er geen scherpe definitie van 'staatsnood' te geven is en het geschreven noodrecht ook reeds toepasbaar is in gevallen waarin de staat als zodanig niet getroffen wordt. ${ }^{12}$ Hiermee sluit hij aan bij een betoog dat 60 jaar geleden al werd gehouden door W.F. Prins. ${ }^{13}$

In het geschreven noodrecht heeft de wetgever geanticipeerd op optreden door de overheid in buitengewone omstandigheden. De wetten die daarvoor tot stand zijn gekomen, leiden in normale omstandigheden een sluimerend bestaan om in noodsituaties in werking te kunnen treden. Het gecodificeerde noodrecht wordt daarom wel gekenschetst als 'recht in de diepvries'I4 of 'waakvlam-wetgeving'. ${ }^{\text {I5 }}$ De regels van staatsnoodrecht zijn overigens niet alleen te vinden in speciale noodwetten maar ook in normale wetten, in de vorm van een ontsnappingsbepaling voor noodsituaties.

\subsection{Begrippen: uitzonderingstoestand als overkoepelend begrip voor een buitengewoon rechtsregime}

De term die in het hedendaagse Nederlandse constitutionele recht gebruikt wordt voor een noodtoestand op rijksniveau is: 'uitzonderingstoestand'. Bij de grondwetsherziening van I983 werd dit begrip in artikel I03 Grondwet geïntroduceerd als overkoepelend begrip voor verschillende typen noodtoestanden, voor I983 werd in het grondwettelijke noodtoestandenartikel (toen: artikel 202) verwezen naar 'de staat van oorlog' en 'de staat van beleg'.

Van belang is dat de term uitzonderingstoestand ziet op een bijzonder rechtsregime. Er moet onderscheid gemaakt worden tussen de noodsituatie, de feitelijke bedreiging van de orde en veiligheid, en de nood- of uitzonderingstoestand. Die laatste is de juridische reactie van de overheid op een feitelijke veiligheidsbedreiging. ${ }^{16}$ In het Nederlandse staatsnoodrecht wordt in dit verband veelal gesproken van buitengewone omstandigheden en buitengewone rechtstoestand. In buitengewone omstandigheden kunnen buitengewone bevoegdheden worden uitgeoefend (die tijdens de normale rechtstoestand een sluimerend bestaan leiden). Indien een buitengewone bevoegdheid kan worden toegepast, is voor het betreffende deelterrein van het recht een buitengewone rechtstoestand ingetreden. De 'buitengewone rechtstoestand' vormt het rechtsgevolg als de voorwaarde 'buitengewone omstan-

II H.R.B.M. Kummeling, 'Recht in nood', Handelingen Nederlandse Juristen-Vereniging 20I4-I (preadviezen), p. 267.

I2 Ibidem.

I3 W.F. Prins, 'Noodstaatsrecht', Rechtsgeleerd Magazijn Themis I956, p. 77-78.

I4 Aldus P.W. Oosterhof, 'Oorlogsgevaar', Militair Rechtelijk Tijdschrift 1952, p. 73.

I5 E.T. Brainich von Brainich Felth, Staatsnoodrecht (diss. Leiden), Zwolle: W.E.J. Tjeenk Willink I993, p. xiv.

I6 Vgl. G. Camus, L'état de necessité en démocratie (diss. Caen), Paris: Pichon et Durand-Auzias I965, p. I5, die het bestaan van een noodsituatie beschouwt als 'l'élément objectif de l'état de necessité'. Ook N. Questiaux, Study of the implications for human rights of recent developments concerning situations known as states of siege or emergency, UN Sub-commission on Prevention of Discrimination and Protection of Minorities, E/CN.4/Sub.2/I982/I5, 27 juli I982, p. 8 maakt dit onderscheid. 
digheid' is vervuld. ${ }^{17}$ De buitengewone omstandigheden hoeven in de tijd niet volledig samen te vallen met het bestaan van en buitengewone rechtstoestand. Als voor het intreden van een buitengewone rechtstoestand een formeel besluit is vereist, dan ontstaat de buitengewone rechtstoestand later dan het moment waarop de buitengewone omstandigheid zich voor het eerst heeft gemanifesteerd. ${ }^{18}$

Historisch gezien zijn in Nederland verschillende typen van uitzonderingstoestanden onderscheiden. De staat van oorlog en de staat van beleg werden al eerder genoemd. Daarnaast waren er de toestand van verhoogde waakzaamheid, de burgerlijke uitzonderingstoestand en de toestand van oorlogsgevaar. Aangezien dit preadvies zich richt op de huidige publiekrechtelijke noodtoestanden zie ik ervan af om nader in te gaan op het precieze karakter van deze voormalige typen van noodtoestanden. Opvallend is dat in artikel 34 van het Statuut voor het Koninkrijk, dat van hogere orde is dan de Grondwet, nog altijd verwezen wordt naar de oude grondwettelijke begrippen staat van oorlog en staat van beleg. ${ }^{19}$ Het uit 1954 stammende Statuut is niet aangepast aan de moderne (grond)wettelijke terminologie en verwijst nu naar noodtoestanden die we, althans in het Nederlandse recht, niet meer kennen. Overigens laat ik een verdere bespreking van dit artikel uit het Statuut ook achterwege: de volgens het tweede lid van dit artikel vereiste rijkswet, die het uitroepen van deze noodtoestanden en de gevolgen ervan zou moeten regelen voor het gehele koninkrijk, is nooit tot stand gebracht. De landen van het koninkrijk hebben elk eigen wetgeving met betrekking tot het uitroepen van enigerlei noodtoestand.

Naast de buitengewone juridische regimes die kunnen worden ingesteld in situaties van nood kent Nederland sinds juni 2004 ook een alerteringssysteem voor bedrijven en overheidsinstanties in het kader van de terrorismebestrijding: Atb. Dit systeem voorziet in diverse 'alerteringsfasen', afhankelijk van het dreigingsniveau van terroristische aanslagen. Aan de hand van dreigingsinformatie van de NCTV worden in de verschillende alerteringsfasen meer of minder (pakketten van) beveiligingsmaatregelen getroffen, zowel door de overheid als door bedrijfssectoren, ter voorkoming van een aanslag of ter beperking van het effect ervan. Bij het treffen van deze beveiligingsmaatregelen gaat het echter in beginsel niet om het uitoefenen van noodbevoegdheden of het in werking stellen van noodwetgeving. Het gaat veeleer om intensivering van het gebruik van 'normale' bevoegdheden van politie- en andere autoriteiten, zoals intensieve politiesurveillance in bepaalde gebieden, grenscontrole, bewaking van bepaalde objecten, installaties en personen, verscherpen dan wel extra invoeren van cameratoezicht of preventief fouilleren (bijvoorbeeld op luchthavens of stations), het uitvaardigen van verboden om bepaalde gebieden te betreden, het evacueren van personen uit gebieden waar een aanslag verwacht wordt (of is aangekondigd). ${ }^{20}$ Het Atb verandert niets aan het Nederlandse stelsel van noodwettelijke maatregelen. Parallel

I7 Zie art. I Coördinatiewet uitzonderingstoestanden.

I8 Brainich I993, p. 9-Io.

I9 Art. 34, eerste lid, Statuut voor het Koninkrijk luidt: 'De Koning kan ter handhaving van de uit- of inwendige veiligheid, in geval van oorlog of oorlogsgevaar of ingeval bedreiging of verstoring van de inwendige orde en rust kan leiden tot wezenlijke aantasting van belangen van het Koninkrijk, elk gedeelte van het grondgebied in staat van oorlog of in staat van beleg verklaren.'

Kamerstukken II 2007/08, 3I 499, nr. I (verslag van onderzoek door Rekenkamer naar functioneren Atb). 
aan het alerteringssysteem functioneert het DTN, het Dreigingsbeeld Terrorisme Nederland, een periodieke publicatie door de NCTV die meer gericht is op brede publieksvoorlichting omtrent de actuele terrorismedreiging. Aan de vijf dreigingsniveaus die in het DTN worden onderscheiden is echter geen standaardpakket bevoegdheden of maatregelen verbonden dat bij het bereiken van een bepaald niveau wordt, of kan worden, ingezet. ${ }^{21}$

\subsection{Veiligheidsbedreigingen en vitale belangen}

De hedendaagse opvatting over veiligheid en veiligheidsbedreigingen heeft zich gevormd in het post 9/11-tijdperk. Tot die tijd hanteerden beleidsmakers een dichotoom veiligheidsconcept bestaande uit interne en externe veiligheid. ${ }^{22}$ De terreuraanslagen in de Verenigde Staten van 200 I makten pijnlijk duidelijk dat externe gebeurtenissen wereldwijde effecten kunnen veroorzaken. Illustratief voor die wereldwijde effecten is het feit dat naar aanleiding van de aanslagen in de VS in het Verenigd Koninkrijk een noodtoestand werd uitgeroepen, althans een buitengewoon rechtsregime tot stand werd gebracht (de Anti-Terrorism, Crime and Security Act 2001) dat een afwijking van de gebruikelijke grondrechtelijke waarborgen rondom vrijheidsbeneming inhield (in hoofdstuk 5 kom ik daarop nog terug). De begrippen interne en externe veiligheid lijken dan ook niet langer te voldoen om de werkelijkheid van veiligheidsbedreigingen afdoende te omvatten, vooral omdat die begrippen zich in overwegende mate richten op vormen van ordehandhaving.

In zijn preadvies 'Crisis en recht' voor de jaarvergadering van de Nederlandse Juristenvereniging in 2014 gaf Muller aan 'crisisbeheersing' niet louter te beschouwen als maatregelen en voorzieningen ter handhaving van de openbare orde, maar breder te zien: 'Crisis gaat om meer dan alleen openbare orde namelijk om de bedreiging van alle vitale belangen' [curs. JPL]. ${ }^{23}$ Vervolgens onderscheidt hij vijf vitale belangen die zowel op lokaal, regionaal als nationaal niveau aangetast kunnen worden. De omschrijving van deze vijf vitale belangen ontleent hij aan de in 2007 door het kabinet vastgestelde 'Strategie nationale veiligheid'. ${ }^{24}$ In deze strategie is een bedreiging van de nationale veiligheid aan de orde als de aantasting van één of meer vitale belangen gepaard gaat met (een aanzienlijk risico op) maatschappelijke ontwrichting:

'De nationale veiligheid is in het geding als vitale belangen van onze staat en/of onze samenleving zodanig bedreigd worden dat sprake is van - potentiële - maatschappelijke ontwrichting. Nationale veiligheid omvat zowel aantasting van de veiligheid door opzettelijk menselijk handelen (security) als aantasting door rampen, systeem- of procesfouten, menselijk falen of natuurlijke anomalieën zoals extreem weer (safety). ${ }^{25}$

2I Vgl. Edwin Bakker \& Jeanine de Roy van Zuijdewijn, Barometer van de dreiging. Tien jaar Dreigingsbeeld Terrorisme Nederland 2005-2015, Den Haag: NCTV december 2015.

22 P. Ducheine, 'Je heeft geen zwaard en schild te dragen om ridder te zijn'. Mythen over digitale oorlogsvoering en recht (oratie UvA), Amsterdam 20I6, p. 7 .

23 E.R. Muller, 'Crisis en recht', Handelingen Nederlandse Juristen-Vereniging 20I4-I (preadviezen), p. 5.

24 Bijlage bij Kamerstukken II 2006/07, 30 82I, nr. 3. Ook te raadplegen via: https://www.nctv.nl/ binaries/strategie-nationale-veiligheid-2007_tcm3I-32502.pdf.

Strategie nationale veiligheid 2007, p. 9. 
'I. Territoriale veiligheid. Het ongestoord functioneren van Nederland als onafhankelijke staat, en specifieker de territoriale integriteit van ons land. De territoriale integriteit is in gevaar bij bijvoorbeeld een dreigende bezetting van het grondgebied van het rijk door een andere mogendheid, maar ook door een terroristische aanslag.

2. Economische veiligheid. Het ongestoord functioneren van Nederland als een effectieve en efficiënte economie. De economische veiligheid kan bijvoorbeeld aangetast worden als het handelsverkeer met een belangrijke buitenlandse partner uitvalt.

3. Ecologische veiligheid. Het beschikken over voldoende zelfherstellend vermogen van de leefomgeving bij aantasting. De ecologische veiligheid kan in het geding komen door bijvoorbeeld verstoringen in het beheer van het oppervlaktewater, maar ook door klimaatveranderingen.

4. Fysieke veiligheid. Het ongestoord functioneren van de mens in Nederland en zijn omgeving. De fysieke veiligheid staat bijvoorbeeld onder druk als de volksgezondheid wordt bedreigd door de uitbraak van een epidemie, maar ook bij een grootscheepse dijkdoorbraak of een ongeluk in een chemische fabriek.

5. Sociale en politieke stabiliteit. Het ongestoorde voortbestaan van een maatschappelijk klimaat waarin groepen mensen goed met elkaar kunnen samenleven binnen de kaders van de democratische rechtsstaat en gedeelde kernwaarden. De sociale en politieke stabiliteit kan in het geding zijn als veranderingen optreden in de demografische opbouw van de samenleving (bijvoorbeeld solidariteit tussen generaties), de sociale cohesie en de mate van deelname van de bevolking aan maatschappelijke processen.'

Onder de economische veiligheid valt ook de stabiliteit van energielevering (olie, gas, elektriciteit), van het financieel verkeer en van het telecommunicatienetwerk, alsmede het functioneren van de transportinfrastructuur en transportcapaciteit. $\mathrm{Bij}$ de fysieke veiligheid moet niet alleen worden gedacht aan rampenbestrijding en gezondheidszorg, maar ook aan zaken als waterbeheer, levering van drinkwater, voedselvoorziening en voedselveiligheid. Nauw verwant met de territoriale integriteit is het functioneren van de nationale rechtsorde: het functioneren van het openbaar bestuur, van de rechtshandhaving en rechtspleging en van de detentie-instellingen. ${ }^{26}$

Daarnaast wordt vaak nog de internationale rechtsorde, waarin vrede en veiligheid centraal staan, genoemd als een vitaal belang waarvan de staat de behartiging aan zich heeft getrokken in het kader van het veiligheidsbestuur. ${ }^{27}$ Dit laatste belang voert zelfs de boventoon. Terecht wordt in de meest recente druk van het Handboek van het Nederlandse staatsrecht opgemerkt dat de ontwikkeling van de internationale verhoudingen (einde Koude Oorlog, opkomst internationale terroristische dreigingen, veiligheidsrisico's die uitgaan van failed states) heeft gemaakt dat de kern van het veiligheidsbeleid vandaag de dag niet meer gevormd wordt door de

26 Vgl. E.T. Brainich von Brainich Felth, Het systeem van crisisbeheersing, Den Haag: Boom Lemma uitgevers 2004, p. I7.

27 D.J. Elzinga, R. de Lange \& H.G. Hoogers (bew.), Van der Pot - Handboek van het Nederlandse staatsrecht, Deventer: Kluwer 20I4, p. 757. 
verdediging van het eigen grondgebied tegen een buitenlandse vijand of dreiging, maar is verschoven richting de handhaving van de internationale rechtsorde. ${ }^{28}$

Een aantasting van één of meer van de bovengenoemde vitale belangen kan een crisis opleveren die een bedreiging voor de nationale veiligheid vormt. Naast dergelijke crises moet worden gewezen op het fenomeen van de digitale crisis. Door de opkomst van moderne informatie- en communicatietechnologie (ICT) is naast de fysieke samenleving een digitale samenleving ontstaan, waarin het internet een belangrijke rol speelt: 'Burgers, overheden en bedrijven gebruiken digitale toepassingen voor online interactie en transacties, efficiënter (samen)werken, communicatie en vermaak. Ook wordt apparatuur met ingebouwde ICT vaker verbonden met het internet: computers en telefoons, maar ook auto's, thermostaten en medische applicaties. ${ }^{29}$ Digitale veiligheid, of cybersecurity, is dan ook van essentieel belang. Een ernstige aantasting daarvan kan zodanige consequenties hebben voor het functioneren van het economisch systeem, van de instanties die de fysieke of territoriale veiligheid moeten waarborgen, of van de samenleving als geheel, dat hierbij de nationale veiligheid in het geding komt. In de Nationale Cybersecurity Strategie uit 2014 omschrijft de NCTV dit als volgt:

'Onze vitale infrastructuur is in toenemende mate afhankelijk van ICT-systemen. Uitval of verstoring van deze systemen of het schenden van de vertrouwelijkheid van daarin opgeslagen informatie door staten en criminelen heeft grote impact. Het kan zelfs leiden tot maatschappelijke ontwrichting. Er is sprake van een toegenomen verwevenheid tussen militaire en civiele, publieke en private en nationale en internationale dimensies in het digitale domein. Zo kan de nationale veiligheid in gevaar worden gebracht door een grootschalige digitale aanval op één of meer private organisaties. ${ }^{30}$

De hierboven genoemde vitale belangen worden als het ware doorsneden door digitale systemen die dusdanig belangrijk zijn dat een aantasting of verstoring daarvan ook op zichzelf aangemerkt kan worden als een aantasting van een vitaal belang. ${ }^{3 \mathrm{I}}$

\subsection{Rechtvaardigingsargumenten in relatie tot typen van veiligheids- bedreigingen: de verschoven staatsnood}

In de rechtswetenschappelijke literatuur wordt vaak de vergelijking gemaakt tussen de staat in nood en het individu, dat een noodweerrecht heeft wanneer hij in zijn bestaan wordt bedreigd. $\mathrm{Al}$ in $\mathrm{I} 884$ schrijft Cleveringa: 'Evenals ieder persoon, iedere vereeniging in geval van noodweer alles mag in 't werk stellen om het dreigend gevaar af te wenden, zóó ook de Staat. ${ }^{32}$ M.I. Prins betoogt in I9II, aan de hand van een aantal voorbeelden, dat de uitvoerende macht nooit in gebreke blijft om, zo nodig met terzijdestelling van de geschreven wet, de zelfstandigheid van de staat te trachten te handhaven en dat dit streven door de meerderheid van de

28 Elzinga, De Lange \& Hoogers 20I4, p. 756.

29 NCTV, Nationale Cybersecurity Strategie 2: Van bewust naar bekwaam, p. I3.

30 Idem, p. 23.

3I Ducheine 20I6, p. 7 .

32 R. Cleveringa, Staat van Oorlog en Beleg (diss. Groningen), Groningen: Wolters I884, p. 5. 
burgers steeds wordt toegejuicht. ${ }^{33}$ Vele andere auteurs komen tot dezelfde constatering. ${ }^{34}$ Kranenburg acht het 'niet aannemelijk' dat in wetgeving vastgelegde normen ook moeten worden toegepast in situaties waarop men bij het tot stand komen van die normen in het geheel niet gerekend heeft of wellicht niet heeft kunnen rekenen. Hij meent:

'De zaak is dan ook, dat men er in het staatsrecht eenvoudig niet buiten kan noodtoestand te aanvaarden als grond voor van de geschreven norm afwijkend staatsnoodrecht bij volkomen onvoorzienbare situaties. Het bestaan zelf van de staatsgemeenschap en van het volk, dat een element van dien staat vormt, kan het eischen, onverbiddelijk, dat van de regeling der orgaan-verhoudingen, zoals de Grondwet deze vaststelt, worde afgeweken; het voortbestaan zelve kan in het uiterste gevaar zijn. ${ }^{35}$

De vergelijking met het zelfverdedigingsrecht van het individu maakt duidelijk dat in de rechtsgeleerde discussie het gebruik van noodtoestanden of regels van staatsnoodrecht gereserveerd wordt voor zeer ernstige veiligheidsbedreigingen: het voortbestaan van de natie of het functioneren van het staatsbestel moet op het spel staan. Men spreekt en schrijft over dit onderwerp met het beeld voor ogen van noodsituaties die qua ernst in de buurt komen van een oorlog.

In de twintigste eeuw heeft zich op dit punt evenwel een ontwikkeling voorgedaan: de belangen ten behoeve waarvan buitengewone bevoegdheden kunnen worden ingezet, zijn uitgebreid. In de eerste plaats zijn veel van de tot stand gebrachte noodwetten erop gericht de maatschappij als zodanig in stand te houden..$^{36}$ Uit de huidige noodwetten kan worden afgeleid dat noodbevoegdheden ook kunnen worden toegepast in noodsituaties die slechts een deel van het land betreffen. En het doelcriterium dat artikel I03 Grondwet geeft voor het uitroepen van een uitzonderingstoestand, 'ter handhaving van de uit- of inwendige veiligheid', heeft niet veel afbakenende kracht. Brainich heeft in verschillende van zijn publicaties gewezen op het feit dat deze begrippen oorspronkelijk inderdaad verwezen naar oorlogsachtige omstandigheden, ofwel door de inval van een buitenlandse vijand, ofwel als gevolg van grootschalig binnenlands oproer. In de loop van de tijd is de betekenis van deze begrippen echter enorm opgerekt en heeft ook de regering opgemerkt dat alle noodwetgeving in beginsel onder artikel I03 Grondwet valt. ${ }^{37}$

Het criterium 'buitengewone omstandigheden', dat in artikel I van de Coördinatiewet uitzonderingstoestanden wordt gehanteerd om aan te geven wanneer buitengewone bevoegdheden kunnen worden ingezet, ziet weliswaar op feitelijke omstandigheden, maar de beoordeling van de aanwezigheid van die buitengewone

33 Prins I9II, p. I-5.

34 O.m. P. Anselme, 'Du respect de la legalité en cas de péril national', Revue critique de législation I9Io, p. 52I; C.L. Rossiter, Constitutional Dictatorship - Crisis Government in the Modern Democracies, Princeton: Princeton University Press 1948, p. I2: 'there is no denying the fact that responsible statesmen in every free country have broken the law in order to protect the nation in time of serious national emergency, and responsible statesmen will do it again. And the nation was always pretty solidly behind them.'

35 R. Kranenburg, 'Staatsnoodrecht' (College voor de oud-alumni der Leidse Universiteit op 6 februari 1946), Tijdschrift voor Overheidsadministratie 1946, p. 90. Zie ook R. Kranenburg (bewerkt m.m.v. J.L. Kranenburg), Nederlandsch Staatsrecht, Haarlem: H.D. Tjeenk Willink I958, p. 26I.

36 Brainich 1993, p. 82-83.

37 Brainich I993, p. 76-88; Brainich 2004, p. 4I; Kamerstukken II I993/94, 23 790, nr. 3, p. 4. 
omstandigheden is uiteindelijk een politiek-juridische. Daarom kan er sprake zijn van buitengewone omstandigheden in kleine en grote noodsituaties..$^{8}$ De kwalificatie buitengewone omstandigheden bestaat uit twee onderdelen, te weten (a) de bedreiging van een vitaal belang en (b) de ontoereikendheid van de normale bevoegdheden. ${ }^{39}$ Daarmee is de inzet van buitengewone bevoegdheden dus niet zozeer gekoppeld aan feitelijke omstandigheden die een bepaalde ernst of omvang moeten hebben, maar vooral aan het antwoord op de vraag of de normale bevoegdheden toereikend zijn om de crisissituatie het hoofd te bieden.

Dit betekent dat in beginsel een aantasting van elk van de in $\$ 2.3$ opgesomde vitale belangen een ernstige veiligheidsbedreiging voor de maatschappij of samenleving kan opleveren. Zeker omdat bij dergelijke veiligheidsbedreigingen vandaag de dag rekening gehouden moet worden met de angstgevoelens en -reacties die deze bij de bevolking kunnen veroorzaken, aangewakkerd door berichten op sociale media. Crisissituaties die als zodanig wellicht niet rechtstreeks een bedreiging voor het bestaan van de natie of het functioneren van het staatsbestel opleveren, kunnen dat door de heftige reacties vanuit de bevolking die daardoor soms met hyperspeed in gang worden gezet, wel gaan doen..$^{\circ}$ De ongrijpbaarheid en snelheid waarmee dit soort situaties zich kunnen ontwikkelen maakt dat de beslissing over het uitroepen van een noodtoestand of het toepassen van staatsnoodrecht al snel heikel en omstreden zal zijn. Het gaat bij de beoordeling of sprake is van buitengewone omstandigheden in wezen om een dubbele beoordeling: een beoordeling van de feitelijke omstandigheden en een beoordeling van de risico's die door inwerkingtreding van de betreffende buitengewone rechtstoestand kunnen worden afgewend. ${ }^{4 \mathrm{I}}$

Daar komt bij dat de accentverlegging binnen het veiligheidsbeleid richting de handhaving van de internationale rechtsorde (zie de vorige paragraaf) maakt dat bij noodsituaties die aanleiding kunnen vormen voor de inzet van noodrechtelijke instrumenten, inclusief de opschorting van mensenrechtelijke verdragsverplichtingen (waarover meer in hoofdstuk 5), niet langer louter gedacht moet worden aan situaties die zijn ontstaan buiten de wil van de betreffende staat of regering. ${ }^{42}$ Deelname aan een militaire interventiemacht - in NAVO- of VN-verband - in een conflictgebied of een instabiele staat die een veiligheidsbedreiging vormt, kan de krijgsmacht van een staat in noodsituaties brengen die door de staat zelf zijn opgezocht. Dat zal doorgaans niet leiden tot juridische ingewikkeldheden ten aanzien van de toepassing van nationaal staatsnoodrecht, maar mogelijk wel waar het gaat om de opschorting van mensenrechtelijke verdragsverplichtingen. De extraterri-

38 E.T. Brainich von Brainich Felth, T\&C Openbare orde en Veiligheid, aant. 3 b bij art. I03 GW.

39 Idem, aant. 3 bij art. Io3 GW en commentaar bij standaardbepaling inwerkingtreding noodwetgeving.

$40 \quad$ Ik denk hierbij niet alleen aan ernstige ordeverstoringen in reactie op een bepaalde aantasting van één of meer van de vitale belangen, maar ook aan een fenomeen als een 'bankrun', waardoor het financieel systeem dreigt in te storten.

4I Vgl. R. de Lange, 'Tussen gelijkheid en waarschijnlijkheid: het evenredigheidsoordeel in uitzonderingssituaties', in: A. Nieuwenhuis, B.J. Schueler \& C.M. Zoethout (red.), Proportionaliteit in het publiekrecht, Deventer: Kluwer 2005, p. I32.

42 De vooronderstelling dat het bij de buitengewone omstandigheden die tot inzet van het staatsnoodrecht nopen moet gaan om een noodsituatie die de staat ongewild overkomt, lijkt bij veel auteurs over dit onderwerp impliciet aanwezig. Camus I965, p. 23 is expliciet: 'L'élément objectif de l'état de nécessité consiste dans l'existence d'une situation de fait, imposée de l'extérieur en dehors de la volonté de ceux qui sont chargés d'élaborer et d'appliquer les règles de droit.' 
toriale werking van deze verplichtingen is onder meer in de jurisprudentie van het EHRM in hoge mate uitgekristalliseerd, waardoor ook naar het buitenland uitgezonden troepen gebonden kunnen zijn aan de soms strenge verdragsstandaarden ten aanzien van geweldgebruik, detentie en onderzoek naar geweldsincidenten. ${ }^{43}$ Dit doet de vraag reizen of staten aan deze strenge standaarden kunnen ontsnappen door gebruikmaking van de opschortingsclausules voor noodsituaties die in de mensenrechtenverdragen zijn opgenomen.

\subsection{Kenmerken van noodtoestanden en noodregimes - en blijvende constitutioneelrechtelijke effecten}

Brainich heeft in zijn proefschrift op heldere wijze in kaart gebracht hoe het noodrecht in de twintigste eeuw van karakter is veranderd en welke kenmerken dit nu heeft. Doordat na de Eerste Wereldoorlog het bestaan van ongeschreven staatsnoodrecht werd erkend, wijzigde het geschreven staatsnoodrecht van het limitatief opsommen van gebeurtenissen die de inzet van vooraf bepaalde bevoegdheden zouden activeren naar (a) het bieden van een leidraad en houvast voor de overheid in voorziene buitengewone omstandigheden (zodat niet op alle vlakken geïmproviseerd moet worden) en (b) het bieden van enige (rechts)zekerheid aan de burgers omdat tevoren is nagedacht over de te treffen noodmaatregelen waarbij de formele wetgever betrokken is bij het maken van de daaraan ten grondslag liggende belangenafweging. ${ }^{4}$

\subsubsection{Bevoegdhedenverschuiving en centralisatie}

De reactie van de overheid op een bepaalde noodsituatie of veiligheidsbedreiging zal uiteraard verschillen naar gelang de feitelijke omstandigheden. Desalniettemin is als algemeen kenmerk van het rechtsregime waarmee gereageerd wordt op een noodsituatie wel aan te wijzen dat sprake is van een afwijking van het normale bevoegdhedenpatroon, veelal een uitbreiding van bevoegdheden gekoppeld aan een zekere centralisatie daarvan (een verschuiving van bevoegdheden van lokale autoriteiten naar regionale of rijksorganen ${ }^{45}$ en soms een verschuiving van bevoegdheden van civiele naar militaire autoriteiten.

In de Nederlandse context is deze centralisatie niet een exclusief fenomeen binnen het staatsnoodrecht, maar maakt deze tot op zekere hoogte ook reeds deel uit van het gewone crisisbeheersingsrecht. De Wet Veiligheidsregio's,${ }^{46}$ die een

43 Zie o.m. R.A. Lawson, 'Really Out of Sight? Issues of Jurisdiction and Control in Situations of Armed Conflict under the ECHR', in: A.C. Buyse (ed.), Margins of Conflict. The ECHR and Transitions to and from Armed Conflict, Antwerp-Cambridge-Portland: Intersentia 20II, p. 57-76; M. Szydlo, 'Extra-Territorial Application of the European Convention on Human Rights after Al-Skeini and Al-Jedda', International Criminal Law Review 20I2, p. 27I-29I. Voor Nederland is in het bijzonder relevant: EHRM 20 november 20I4, nr. 47708/08 (Jaloud/Nederland).

44 Brainich 1993 , p. 76-77.

45 Dit is onder meer duidelijk zichtbaar bij de noodtoestand die in Frankrijk werd uitgeroepen in reactie op de aanslagen in Parijs in november 2015. Zie daarover: J.P. Loof, 'De noodtoestand in Frankrijk na de aanslagen in Parijs. Mensenrechtenbescherming op een lager pitje', TvCR 20I6, p. $153-167$.

46 Zie uitgebreid: E.T. Brainich \& I. Helsloot, 'Wet Veiligheidsregio's', in: E.R. Muller, E.T. Brainich \& L.J.J. Rogier (red.), Tekst \& Commentaar Openbare orde en Veiligheid, Deventer: Kluwer 20I4, p. 635742. 
spilfunctie vervult binnen de wetgeving met betrekking tot crisissituaties, legt weliswaar het principe van decentrale aanpak en verantwoordelijkheid voor de organisatie van brandweerzorg, rampenbestrijding, crisisbeheersing (inclusief handhaving van de openbare orde) en geneeskundige hulpverlening vast, maar verschillende bijzondere wetten die zien op specifieke crisissituaties (denk aan: dierziektebestrijding, kernongevallenbestrijding, infectieziektenbestrijding) leggen de verantwoordelijkheden op een centraal niveau. En ook in de Wet Veiligheidsregio's zelf geeft artikel 39 bij rampen en crises met een bovenlokale impact enkele kernbevoegdheden aan de voorzitter van de veiligheidsregio (in beginsel is dat de burgemeester van de grootste gemeente in de regio). Feitelijk en formeel neemt daarbij de ene burgemeester bevoegdheden van een andere burgemeester over en over dit onderdeel van de wet is bij de totstandkoming dan ook veel discussie geweest. ${ }^{47}$ De wet regelt wel dat de voorzitter achteraf verantwoording moet afleggen aan de afzonderlijke gemeenteraden van de betrokken gemeenten, zij het dat die daaraan dan geen consequenties kunnen verbinden (de raad van gemeente $\mathrm{X}$ kan niet het vertrouwen opzeggen in de burgemeester van gemeente Y). Artikel 39 van de Wet Veiligheidsregio's zorgt dus al voor een zekere centralisering van bevoegdheden bij de voorzitter van de veiligheidsregio. ${ }^{48}$

Een voorbeeld van centralisatie in extremis is te vinden in het 'Besluit houdende tijdelijke herindeling van ministeriële taken in geval van een terroristische dreiging met een urgent karakter'. ${ }^{49}$ In dit besluit krijgt de Minister van (Veiligheid en) Justitie een aantal bevoegdheden van andere ministers toebedeeld, enkele bevoegdheden om aanwijzingen te geven aan decentrale overheden (Commissaris van de Koning en burgemeester) en enkele andere behoorlijk ingrijpende bevoegdheden (bijvoorbeeld het weigeren van asielzoekers aan de grens). Het besluit geeft aan de minister een zogenoemde 'doorzettingsmacht' om snelle besluitvorming te garanderen. Opvallend is dat een besluit met zulke ingrijpende consequenties de vorm kreeg van een 'klein KB', gebaseerd op het grondwetsartikel dat betrekking heeft op de instelling van ministeries. Terecht is deze wankele wettelijke basis voor een zo verstrekkend besluit bekritiseerd..$^{50}$ Opvallend is bovendien dat de 'klein KB'-constructie werd verdedigd omdat snelheid om deze doorzettingsmacht tot stand te brengen vereist was en het $\mathrm{KB}$ zou gelden tot een formeel-wettelijke regeling ter zake tot stand gebracht zou worden. Deze wet is nooit ingediend.

Waar het bovenstaande voorbeeld duidelijk maakt dat in de Nederlandse praktijk ingrijpende bevoegdhedenverschuivingen soms al voor de feitelijke noodtoestand buiten het parlement om geregeld worden, heeft de verschuiving van bevoegdheden tijdens een noodtoestand veelal ook gevolgen voor het medebeslissingsrecht en de uitoefening van de controlerende taak door de volksvertegenwoordigende organen. Pregnant voorbeeld zijn de Londense wetsbesluiten van de Nederlandse regering tijdens de Tweede Wereldoorlog, maar ook in het gemeentelijke noodrecht zien we de uitvaardiging van algemeen verbindende voorschriften in een noodverordening door de burgemeester, waar normaliter de gemeenteraad de

47 Muller 20I4, p. I4.

48 Art. 9 van de wet voorziet in het instellen van 25 veiligheidsregio's in Nederland.

49 Stb. 2005, 662.

50 Zie C. Roorda, 'Noodbevoegdheden van Minister van Justitie zijn onrechtmatig', RM Themis 2009, p. I39-I44. 
verordeningen vaststelt. Ook wat betreft het fenomeen van verminderde controle en medebeslissingsbevoegdheden van de volksvertegenwoordiging valt in Nederland waar te nemen dat dit zich tevens buiten de directe sfeer van de noodwetgeving voordoet. Illustratief is de Wet bijzondere maatregelen financiële ondernemingen, beter bekend als de Interventiewet, uit 20I2. Deze wet is onder meer een reactie op het rapport van de parlementaire enquêtecommissie Financieel stelsel (commissie-De Wit), die de maatregelen genomen door het kabinet tijdens de bankencrisis in 2008 en de schuldencrisis in 2009 onderzocht. ${ }^{51}$ Deze commissie constateerde dat het budget- en inlichtingenrecht van de Tweede Kamer werden geschonden bij het treffen van de noodmaatregelen in de financiële sector. De wet bevat enkele bijzondere interventiebevoegdheden voor de Minister van Financiën: het onmiddellijk verschaffen van een kapitaalinjectie of een staatsgarantstelling aan een systeembank en het (gedeeltelijk) nationaliseren van een systeembank. De mogelijkheden tot controle op de uitoefening van deze bevoegdheden door het parlement zijn echter beperkt: de minister moet wel (eventueel vertrouwelijk) inlichtingen verstrekken aan de Kamer, maar de praktijk in 2008-2009 toonde aan dat het aan tijdigheid en volledigheid van informatie richting de Kamer ontbrak en daar verandert de nieuwe wet in wezen niets aan..$^{52}$

Ten slotte heeft de bevoegdhedenverschuiving soms consequenties voor de mate van toetsing door de rechter. Hier kan opnieuw de in november 2015 door de Franse regering uitgeroepen noodtoestand als voorbeeld dienen. Belangrijk onderdeel van het pakket noodmaatregelen is de mogelijkheid om huiszoekingen te verrichten en huisarrest op te leggen zonder voorafgaande rechterlijke toestemming. In plaats daarvan is er slechts de mogelijkheid om achteraf een rechtmatigheidsoordeel te vragen aan de bestuursrechter. ${ }^{53}$ En opnieuw valt vast te stellen dat het fenomeen van verminderde (voorafgaande) controle door de rechter op de uitoefening van bevoegdheden die diep ingrijpen in de persoonlijke levenssfeer zich in Nederland over de volle breedte van het publiekrecht voltrekt, zonder dat sprake is van noodrecht. ${ }^{44}$

\subsubsection{Tijdelijkheid}

Een tweede belangrijk kenmerk van noodtoestanden en noodregimes is het tijdelijke karakter ervan. Brainich noemt dit de 'intermitterende werking': een noodregeling is alleen bedoeld om in werking te treden in buitengewone omstandigheden; als de omstandigheden weer zijn genormaliseerd moet de noodregeling buiten werking worden gesteld. ${ }^{5}$ De bepaling in de ILC Draft Articles on Responsibility of States for Internationally Wrongful Acts, uit 200I, over het beginsel van necessity

5I Eindrapport parlementaire enquêtecommissie Financieel stelsel, 'Verloren krediet - De balans opgemaakt', Kamerstukken II 20II/I2, 3I 980, nr. 6I.

52 Daniëls 2012, p. I784.

53 Loof 20I6, p. I72-I73.

54 Zie o.m. T. Barkhuysen, M.L. van Emmerik e.a., Adequate rechtsbescherming bij grondrechtenbeperkend overheidsingrijpen, Deventer: Wolters Kluwer 20I4. Vgl. ook het ongevraagde advies van de Afdeling advisering van de Raad van State over rechtsbescherming bij bestuurlijke sancties waarin een discrepantie tussen de ingrijpendheid van de bestuurlijke sancties en de daarbij voorziene bestuursrechtelijke rechtsbescherming wordt gesignaleerd; Stcrt. 2015, nr. 30280 (advies) en Kamerstukken II 20I5/I6, 34 300-VI, nr. 72 (reactie kabinet).

Brainich 1993 , p. 87. 
maakt duidelijk dat ook in het in het internationaal publiekrecht uitgegaan wordt van de noodtoestand als een tijdelijk fenomeen. ${ }^{56}$ De mensenrechtenverdragen gaan hier ook van uit en stellen op bepaalde punten nog wat specifieker eisen (zie nader hoofdstuk 5).

Ook het gemeentelijke noodrecht werkt slechts tijdelijk. De noodbevoegdheden van de burgemeester zijn naar hun aard slechts voor korte tijd geldig. De werkingsduur van een noodbevel op grond van artikel 175 Gemeentewet (Gem.w.) is beperkt tot het moment waarop het bevel is opgevolgd. Noodverordeningen die door de burgemeester op grond van artikel I76 Gem.w. zijn uitgevaardigd vervallen als ze niet in de eerstvolgende raadsvergadering worden bekrachtigd. ${ }^{77}$ En als in de tussentijd de noodsituatie heeft opgehouden te bestaan, moet de burgemeester zelf de noodverordening intrekken. De bestuurlijke ophouding in tijden van nood, waarin artikel I76a Gem.w. voorziet, is volgens de wettekst al evenzeer tijdelijk.

In andere landen wordt de tijdelijkheid van een (nationale) noodtoestand onderstreept door het feit dat de wet die die noodtoestand instelt of bekrachtigt aan een grondwettelijke maximumduur is gekoppeld ${ }^{5}$ of anderszins een horizonbepaling bevat. ${ }^{59}$ Ook in de Nederlandse noodwetgeving is tijdelijkheid van de uitoefening van noodbevoegdheden het devies, ${ }^{60}$ maar zijn op dit punt geen dwingende bepalingen te vinden. Het is aan de minister-president dan wel de Staten-Generaal om een ingestelde noodtoestand te beëindigen, zodra de buitengewone omstandigheden geacht worden voorbij zijn. Een en ander is geregeld in de Coördinatiewet uitzonderingstoestanden (zie nader $\$$ 3.2.2).

\subsubsection{Indringender ingrijpen in de uitoefening van fundamentele rechten en vrijheden}

Belangrijk kenmerk van noodtoestanden en de uitoefening van noodbevoegdheden is dat ze dieper kunnen ingrijpen in de uitoefening van fundamentele rechten en vrijheden dan onder het normale rechtsregime toegestaan is. Ook hier kan de Franse noodtoestand van 2015 weer als illustratie dienen. De voorbeelden van noodbevoegdheden die ik in $\$$ 2.5.I al omschreef, huiszoekingen en huisarrest zonder voorafgaande rechterlijke machtiging, brengen niet alleen een vermindering van de rechterlijke controle, maar betekenen tegelijkertijd een diepere ingreep in de privésfeer van de burgers, namelijk een ingreep die niet vergezeld gaat

56 Zie nader Loof 2005, hoofdstuk 3 en G. Molier, 'The State of exception and Necessity under International Law', in: A. Ellian \& G. Molier, The State of Exception and Militant Democracy in a Time of Terror, Dordrecht: Republic of Letters Publishing 20I2, p. I45-I85.

57 Zie art. I76, derde lid, Gem.w.

58 Een voorbeeld is art. 36 van de Franse Grondwet (maximumduur staat van beleg: I2 dagen) en de Franse wet op de etát d'urgence uit 1955 die, sinds deze wet werd aangepast in november 20I5, de maximumduur van die noodtoestand op 3 maanden stelt. Zie Loof 2016.

59 De Britse antiterrorismewetgeving die op bepaalde punten afwijkingen van het normale rechtsregime bevatte, in het bijzonder waar het de termijn van voorgeleiding van verdachten aan een rechter betrof, placht (en pleegt) een horizonbepaling te bevatten, waardoor die wetgeving jaarlijks of tweejaarlijks opnieuw vastgesteld moet worden door het parlement. Zie Loof 2005, p. 648-664.

6 Z Zie T.D. Cammelbeeck, 'Het staatsnoodrecht herzien: het onvoorzienbare gesystematiseerd', AA I996, p. 765: 'Een buitengewone rechtstoestand is een naar zijn aard tijdelijke (dat wil zeggen een duidelijk begin en einde hebbende) rechtstoestand die onder normale omstandigheden niet in de rechtsorde aanwezig is maar kan worden ingesteld als buitengewone omstandigheden daartoe nopen.' 
van de normale waarborgen (veelal rechterlijke controle) tegen misbruik van de betreffende bevoegdheid.

Andere Europese landen die in het min of meer recente verleden gebruik hebben gemaakt van noodwetgeving - in het kader van de strijd tegen terrorisme (het ging vaak om specifieke, tijdelijke, anti-terrorismewetten - deden dit hoofdzakelijk om af te wijken van de normale mensenrechtelijke waarborgen rondom vrijheidsbeneming (de habeas corpus-rechten), in het bijzonder de tamelijk gedetailleerde verplichtingen op grond van artikel 5 EVRM. Zowel het Verenigd Koninkrijk als Turkije heeft in de afgelopen decennia gewerkt met anti-terrorismewetten die het mogelijk maakten om de periode tussen arrestatie van een terreurverdachte en voorgeleiding aan de rechter (in de Nederlandse terminologie: de periode van inverzekeringstelling) op te rekken tot voorbij het maximum dat volgens de EHRM-jurisprudentie over artikel 5 , derde lid, EVRM is toegestaan. ${ }^{6}{ }^{1}$ Ook de Nederlandse noodwetgeving maakt het mogelijk om af te wijken van de normale bescherming van een aantal fundamentele rechten. In hoofdstuk 3 zal ik daar nader op ingaan. Te denken valt dan aan maatregelen als het verbieden van demonstraties, andere openbare samenkomsten en vergaderingen, het verbieden van publicaties of vertoningen, het invoeren van censuur en dergelijke. In de sfeer van vrijheidsbeneming biedt de noodwetgeving zelfs de mogelijkheid van langdurige bestuurlijke detentie (internering) van (groepen) personen die als een gevaar voor de nationale veiligheid worden beschouwd.

\subsubsection{Blijuende gevolgen in het rechtssysteem}

In 2003 bracht Gross op prangende wijze de impact van noodtoestanden op het rechtssysteem onder woorden, ook in landen die zich laten voorstaan op het zijn van democratische rechtsstaat:

'Experience shows that when grave national crises are upon us, democratic nations tend to race to the bottom as far as the protection of human rights and civil liberties, indeed of basic and fundamental legal principles, is concerned. Emergencies suspend, or at least redefine, de facto, if not de jure, much of our cherished freedoms and rights. ${ }^{62}$

Het is met name het herdefiniëren van mensenrechtenbescherming dat ik hier nog nader wil toelichten. Er is een relatie tussen het 'normale' staatsrecht en het staatsnoodrecht, in die zin dat de toepassing van staatsnoodrecht in een bepaalde periode menigmaal leidt tot blijvende veranderingen in de staatsstructuur.

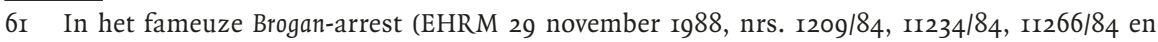
II386/85 (Brogan e.a./VK)) bepaalde het EHRM dat een periode van 4 dagen en 6 uur alvorens voorgeleiding aan de rechter plaatsvond een schending van art. 5, derde lid, opleverde. Zie over dit arrest en de Britse reactie daarop - nl. het uitroepen van een noodtoestand en het opschorten van de verdragsverplichtingen onder art. 5, derde en vijfde lid, - J.P. Loof, 'Brogan en de staatsnood van artikel I5 EVRM; of hoe het Europese Hof Noord-Ierland een noodtoestand bezorgde', annotatie bij EHRM 29 mei 1993, Series A vol. 248-B (Brannigan en McBride/VK), NJCM-Bulletin I993, p. 793-8ro. In Nederland vormde het arrest Brogan aanleiding om de termijn waarbinnen een in verzekering gestelde verdachte uiterlijk voor de rechter-commissaris moet worden geleid op 3 dagen en 55 uur te stellen, zie art. 59a Sv.

62 O. Gross, 'Chaos and Rules: Should Responses to Violent Crises Always Be Constitutional?', The Yale Law Journal 2003, p. Iorg. 
De historische studie van Rossiter uit 1948 heeft dit duidelijk in kaart gebracht. ${ }^{63}$ Verschillende normale overheidsbevoegdheden van nu waren in het verleden buitengewone bevoegdheden. Een duidelijk voorbeeld in Nederland is het huurrecht. ${ }^{64}$

Ook waar het gaat om de bescherming van fundamentele rechten en vrijheden is de druk om de uitoefening van bepaalde inbreukmakende bevoegdheden die aanvankelijk ingeroepen werden om het hoofd te bieden aan een bepaalde noodsituatie te continueren, of in ieder geval blijvend achter de hand te hebben, voelbaar. Een recent Nederlands voorbeeld hiervan biedt de parlementaire behandeling van het wetsvoorstel 'Tijdelijke wet bestuursrechtelijke maatregelen terrorismebestrijding'. ${ }^{65}$ Bij de behandeling van dit wetsvoorstel in de Tweede Kamer pleitten verschillende partijen al voor een permanente status van de in dit wetsvoorstel voorziene maatregelen. ${ }^{66}$

\section{Noodtoestanden in het constitutionele recht}

\section{I Oorlog - artikel 96 en 100 Grondwet}

Aangezien een oorlog allicht te beschouwen valt als de meest vergaande vorm van noodsituatie is het goed om op deze plaats beknopt stil te staan bij de grondwetsbepalingen die hierop betrekking hebben. Artikel 96 Grondwet impliceert dat de bevoegdheid om het Koninkrijk in oorlog te verklaren berust bij de regering, ${ }^{67}$ maar dat voor het uitoefenen van deze bevoegdheid de voorafgaande toestemming van het parlement - en wel de Staten-Generaal in Verenigde Vergadering - vereist is (behoudens de situaties waarin verlening van deze toestemming feitelijk onmogelijk is). Voorafgaande toestemming is eveneens nodig voor een verklaring dat een oorlog beëindigd is. De voorafgaande toestemming van de Staten-Generaal is niet vereist voor het feitelijk inzetten van militaire middelen of feitelijk gebruiken van wapengeweld, maar slechts voor het afleggen van een oorlogsverklaring. ${ }^{68}$ Artikel 96 heeft in wezen geen praktische betekenis, want de oorlogsverklaring is sinds de oprichting van de Verenigde Naties in onbruik geraakt. ${ }^{69}$ Bovendien geeft het artikel niet aan in welke gevallen inoorlogverklaring nodig is, de beslissing om hiertoe een voorstel te doen aan de Staten-Generaal ligt puur bij de regering.

In de afgelopen jaren hebben zich op dit punt wel wat schimmige situaties voorgedaan. Nederlandse troepen maakten onder meer deel uit van de militaire missie in NAVO-verband in het conflict rond Kosovo in 1999, deden vanaf 200 I mee aan de operatie 'Enduring Freedom' in Afghanistan en maakten in 2003 deel uit van de zogenoemde 'stabilisatiemacht' in Irak na de eerdere Amerikaans-Britse inval

63 Rossiter I948, p. I3: 'No democracy ever went through a period of thoroughgoing constitutional dictatorship without some permanent and often unfavorable alteration in its governmental scheme.'

64 Brainich 1993, p. 87.

65 Kamerstukken II 20I5/I6, 34 359, nr. I-5. Zie hierover: College voor de Rechten van de Mens, Mensenrechten in Nederland 2015, Utrecht 20I5, p. 26-27.

66 Kamerstukken II 2015/I6, 34 359, nr. 9.

67 Kamerstukken II I977/78, I5049 (R IIoo), nr. 3, p. I4.

68 J.W.A. Fleuren, T\&C Grondwet, commentaar op art. $96 \mathrm{GW}$.

69 J. van Schooten-van der Meer, 'De oorlogsverklaring', in: P.P.T. Bovend'Eert, L.F.M. Besselink \& J. van Schooten-van der Meer, Grondwet, krijgsmacht en oorlog, Nijmegen: WLP 2008, p. 39-66. 
aldaar, die zonder adequaat VN-mandaat had plaatsgevonden (de stabilisatiemacht was wel gebaseerd op een resolutie van de VN-Veiligheidsraad). ${ }^{7 \circ}$ In al deze gevallen verrichtten Nederlandse troepen feitelijke militaire activiteiten zonder dat het land in oorlog was verklaard.

Belangrijker en praktisch relevanter is artikel roo Grondwet dat ziet op het vooraf verstrekken van inlichtingen door de regering aan de Staten-Generaal over de inzet of het ter beschikking stellen van de krijgsmacht ter handhaving of bevordering van de internationale rechtsorde. Het begrip 'handhaving van de internationale rechtsorde' is ontleend aan artikel $39 \mathrm{VN}-\mathrm{Handvest}$ en ziet op militair optreden vanwege schendingen van de internationale rechtsorde. De term 'bevordering' sluit aan bij artikel 90 Grondwet en ziet op alle maatregelen die aan de internationale rechtsorde dienstig zijn. ${ }^{71}$ Deze maatregelen mogen niet in strijd zijn met het Handvest van de Verenigde Naties. ${ }^{72}$ De bevordering van de internationale rechtsorde omvat ook de verlening van humanitaire hulp in het buitenland, zowel binnen als buiten gewapend conflict. ${ }^{73}$ Ook als de krijgsmacht voor dit soort taken wordt ingezet zal het parlement derhalve voorafgaand geïnformeerd moeten worden.

De politieke realiteit is dat de inlichtingenplicht van artikel roo in de praktijk uitmondt in een instemmingsrecht. De regering heeft zich verzet tegen een dergelijke uitleg van artikel Ioo $^{74}$ en zij vindt de staatsrechtelijke doctrine aan haar zijde.75 De Tweede Kamer pleegt aan het einde van de beraadslaging over een zogeheten 'artikel roo brief' van de regering, waarin een besluit tot inzet van de krijgsmacht is vervat, in een motie een instemmend oordeel uit te spreken met het besluit van de regering. Dit is echter slechts een motie en die is dus niet bindend voor het kabinet. Van een formeel instemmingsrecht is dus geen sprake. In de praktijk zal een kabinet evenwel doorgaans brede steun in de Staten-Generaal zoeken voor het nemen van beslissingen over de inzet van de krijgsmacht in het kader van de internationale rechtsorde. Dat neemt niet weg dat de omvang van de parlementaire betrokkenheid bij de inzet van de krijgsmacht herhaaldelijk vragen oproept. ${ }^{76}$

Tegelijkertijd zijn er wel redenen te bedenken waarom codificering van de politieke praktijk - steun van een (ruime) meerderheid van de Tweede Kamer is nodig voor de inzet van Nederlandse troepen in het kader van de handhaving van de internationale rechtsorde - in de Grondwet wellicht niet de voorkeur heeft. Militaire bijstandsverplichtingen in bondgenootschappelijk verband (artikel 5 NAVO-verdrag) en handelingssnelheid in echt onvoorziene noodsituaties kunnen op gespannen voet staan met een formeel parlementair instemmingsrecht.

70 Zie het beknopte overzicht in Elzinga, De Lange \& Hoogers 20I4, p. 762-763. In 20Io oordeelde de commissie-Davids dat voor de inval in Irak geen adequate volkenrechtelijke basis aanwezig was (Kamerstukken II 2009/10, 3I 847, nr. I8).

$7 \mathrm{I}$ J.W.A. Fleuren, T\&C Grondwet, commentaar op art. Ioo GW.

72 Kamerstukken II I997/98, 25367 (R I593), 5, p. 6.

73 Kamerstukken I I997/98, 25367 (R I593), 226b, p. 2-3.

74 Handelingen II I997/98, p. 3246-3247.

75 Vgl. P.P.T. Bovend'Eert, T\&C Grondwet, commentaar op art. Ioo GW, aant. 5; Elzinga, De Lange \& Hoogers 20I4, p. 758-765.

76 Zie Kamerstukken II 2005/06, 30 I62, nr. 2 en 3 (Rapport 'Inzet met instemming. De rol van de Tweede Kamer bij het uitzenden van militairen'); P.P.T. Bovend'Eert, L.F.M. Besselink \& J. van Schooten-van der Meer, Grondwet, krijgsmacht en oorlog, Nijmegen: WLP 2008; A. Kristić, De Staten-Generaal en de inzet van de Nederlandse krijgsmacht (diss. Tilburg), Deventer: Kluwer 2012. 
In 200I, na 9/11, stelde de regering zich op het standpunt dat militaire bijstand aan de VS op grond van artikel 5 NAVO-verdrag zelfs niet onder de mededelingsplicht van artikel Ioo Grondwet viel. Dit standpunt is door diverse staatsrechtjuristen bekritiseerd, ${ }^{77}$ een eerder kabinet had ook iets anders beweerd.$^{78}$

\subsection{Uitzonderingstoestanden - artikel ro3 Grondwet}

Zoals in de inleiding reeds opgemerkt bevat de huidige Nederlandse Grondwet in artikel Io3 een bepaling die het mogelijk makt om in buitengewone omstandigheden af te wijken van het normale constitutionele regime. Het eerste lid van dit artikel bepaalt dat in dat soort gevallen bij koninklijk besluit een bij de wet aan te wijzen uitzonderingstoestand kan worden afgekondigd. Daarbij kan ingevolge het tweede lid eventueel worden afgeweken van een aantal bepalingen van de Grondwet, waaronder enkele grondrechtenbepalingen.

Artikel I03 Grondwet luidt:

'I. Dewetbepaaltin welkegevallen ter handhavingvan de uit- of inwendigeveiligheid bij koninklijk besluit een door de wet als zodanig aan te wijzen uitzonderingstoestand kan worden afgekondigd; zij regelt de gevolgen.

2. Daarbij kan worden afgeweken van de grondwetsbepalingen inzake de bevoegdheden van de besturen van provincies, gemeenten en waterschappen, van de grondrechten geregeld in de artikelen 6 , voor zover dit de uitoefening buiten gebouwen en besloten plaatsen van het in dit artikel omschreven grondrecht betreft, 7, 8, 9, I2, tweede lid, en I3, alsmede van artikel II3, eerste en derde lid.

3. Terstond na de afkondiging van een uitzonderingstoestand en voorts, zolang deze niet bij koninklijk besluit is opgeheven, telkens wanneer zij zulks nodig oordelen beslissen de Staten-Generaal omtrent het voortduren daarvan; zij beraadslagen en besluiten ter zake in verenigde vergadering.'

Naast artikel I03 bevat ook artikel I4 Grondwet, over onteigening, een bepaling die afwijking van het normale grondwettelijke en grondrechtelijke beschermingsregime mogelijk maakt. Waar de hoofdregel van artikel I4, in het eerste lid, aangeeft dat onteigening slechts mogelijk is in het algemeen belang en tegen een vooraf vastgestelde schadeloosstelling, stelt het tweede lid dat die schadeloosstelling niet vooraf verzekerd hoeft te zijn 'wanneer in geval van nood onverwijld onteigening geboden is'.

\subsubsection{Historische achtergrond}

De huidige tekst van artikel I03 is vastgesteld bij de grondwetsherziening van 1983 . De wortels zijn echter ouder en liggen in artikel I87 van de Grondwet I887. Dat artikel werd indertijd in de Grondwet opgenomen om een basis te creëren voor

77 L.F.M. Besselink, 'Militaire acties en de rol van het parlement', NJB 200I, p. I883-I887; P.P.T. Bovend'Eert \& H.R.B.M. Kummeling, Het Nederlandse Parlement, Deventer: Kluwer 20I0, p. 364 .

78 Handelingen I I997/98, p. 22-I072. 
noodwetgeving waarin werd afgeweken van de Grondwet. Die basis was er voor I887 niet, hoewel toen wel noodwetgeving voorkwam die een inbreuk maakte op bijvoorbeeld de grondwettelijke bevoegdhedentoedeling. ${ }^{79}$ Aangezien in die tijd oorlogvoering als een strikt militaire taak werd gezien, konden op grond van artikel I87 Grondwet I887 alleen aan het militair gezag buitengewone bevoegdheden worden toegekend. Het burgerlijk gezag leverde slechts bevoegdheden in. ${ }^{80}$ Artikel I87 gaf de mogelijkheid tot het instellen van twee uitzonderingstoestanden, namelijk de staat van oorlog en de staat van beleg. Daarbij was de staat van oorlog een overgangstoestand tussen de normale rechtstoestand en de staat van beleg, die de meest verstrekkende afwijkingsmogelijkheden bood. Artikel I87 bood ook de mogelijkheid af te wijken van (de normale beperkingsmogelijkheden in) enkele grondrechtenbepalingen in de toenmalige Grondwet, te weten de bepalingen met betrekking tot de vrijheid van drukpers, de vrijheid van vereniging en vergadering, het huisrecht, het briefgeheim en het ius de non evocando.

De structuur en het bereik van het huidige artikel I03 Grondwet komen nog in grote mate overeen met die van artikel I87 uit I887. De grondrechtenbepalingen waarvan op grond van artikel I03 Grondwet I983 afwijking mogelijk is, bevatten grofweg dezelfde rechten als de grondwetsartikelen waarvan in I887 kon worden afgeweken. Bovendien moest ook op grond van de bepaling uit 1887 het uitroepen van de uitzonderingstoestand reeds bij koninklijk besluit geschieden, waarbij dit alleen mocht plaatsvinden in geval van de bij wet omschreven omstandigheden en op in die wet geregelde wijze.

Een verandering ten opzichte van 1887 is dat het huidige artikel 103 Grondwet niet meer aangeeft wélke uitzonderingstoestanden uitgeroepen kunnen worden. Volgens artikel I03 kan de wetgever een onbeperkt aantal uitzonderingstoestanden introduceren, mits deze dienen 'ter handhaving van de uit- of inwendige veiligheid'.

\subsubsection{Parlementaire betrokkenheid bij uitzonderingstoestand}

In het derde lid van artikel I03 Grondwet is expliciet opgenomen dat de StatenGeneraal zo spoedig mogelijk na het regeringsbesluit (koninklijk besluit op voordracht van de minister-president) tot instelling van een uitzonderingstoestand moeten beslissen over het voortduren van die uitzonderingstoestand. Deze beslissing is niet afhankelijk van het indienen van een wetsvoorstel door de regering, zoals onder het oude grondwettelijke regime gebruikelijk was (en waarbij het indienen van dit wetsvoorstel nog wel eens lang op zich liet wachten). ${ }^{81}$ Dit moet gebeuren in een verenigde vergadering van de Tweede en Eerste Kamer. De Grondwet geeft geen regels voor de procedure van de parlementaire besluitvorming ter zake. Dat gebeurt wel in de Coördinatiewet uitzonderingstoestanden, de centrale wet ter uitvoering van artikel I03, die hieronder verder zal worden besproken. Bij de totstandkoming daarvan lichtte de regering toe dat, om rechtsonzekerheid

79 Brainich 1993 , p. 24.

8 Idem, p. 25 .

8I T.B. Kuitert, 'In geval van nood', in: Gegeven de Grondwet (CZW-bundel), Deventer: Kluwer I988, p. I66-I67 en I74, noemt enkele voorbeelden van rond de Eerste Wereldoorlog waarin het enkele maanden duurde voordat een wetsvoorstel tot verlenging van een noodtoestand bij de Tweede Kamer werd ingediend. 
te voorkomen, een besluit van de Staten-Generaal inzake het al dan niet voortduren van de uitzonderingstoestand 'rechtstreekse werking toekomt'. ${ }^{82}$ Bedoeld is dat dit besluit onmiddellijk effect heeft, zonder nadere uitvoeringsbesluiten van regeringszijde.

Artikel I8 van het Reglement van orde van de verenigde vergadering der Staten-Generaal bepaalt dat een besluit van de verenigde vergadering bij meerderheid van stemmen genomen wordt, tenzij de Grondwet anders vereist. Nu dit niet het geval is, volstaat dus een gewone meerderheid.

\subsubsection{Erkenning subjectief noodrecht door grondwetgever}

Bij de totstandkoming van artikel I03 Grondwet heeft de grondwetgever er uitdrukkelijk voor gekozen om niet alle denkbare afwijkingen van de Grondwet te regelen. Zo bepaalt het artikel dat slechts kan worden afgeweken van de bevoegdheden van de decentrale overheden. De regering achtte het niet gewenst de mogelijkheid te bieden tot afwijking van de grondwettelijke bevoegdheden van de centrale overheid (regering en Staten-Generaal). ${ }^{83}$ Tegelijkertijd gaf de regering aan niet uit te sluiten dat zich situaties zouden kunnen voordoen die - ook buiten artikel I03 om - tot afwijking van de in de Grondwet neergelegde constitutionele ordening zouden noodzaken. Als voorbeeld werd in het parlementaire debat genoemd het niet meer functioneren van de Staten-Generaal, zoals tijdens de Tweede Wereldoorlog. De regering achtte het echter niet wenselijk een algemene en naar zijn aard vrijwel onbegrensde bevoegdheidsgrondslag voor overheidsoptreden in situaties van staatsnood te codificeren, onder meer vanwege het potentiële gevaar van misbruik. Het erkennen van het bestaan, maar het niet-vastleggen van zo'n bevoegdheid in de Grondwet zou de beste waarborg vormen om onverantwoord en ongerechtvaardigd gebruik ervan te voorkomen. ${ }^{84}$

Vanuit het parlement kwam geen duidelijk protest tegen deze visie, zodat ook de grondwetgever impliciet heeft erkend dat er buiten de Grondwet om ruimte is voor toepassing van ongeschreven noodrecht op basis van het ongeschreven (staats)noodrecht.

\subsubsection{Systematiek afwijking grondrechten}

Wat de grondrechten betreft is in artikel I03 Grondwet gekozen voor een limitatieve opsomming van grondwettelijke bepalingen waarvan mag worden afgeweken. Afwijken is mogelijk van de normale grondwettelijke bescherming van de godsdienstvrijheid, voor zover de uitoefening daarvan plaatsvindt buiten gebouwen en besloten plaatsen, van de vrijheid van meningsuiting, van de verenigingsvrijheid, van de vergader- en demonstratievrijheid, van het huisrecht (de procedurele waarborgen rondom binnentreden in woningen zonder toestemming van de bewoner) en van het telecommunicatiegeheim (briefgeheim, telefoon- en telegraafgeheim, mede omvattend andere vormen van telecommunicatie).

82 Kamerstukken II I993/94, 23 79o, nr. 3, p. 8.

83 Kamerstukken II I979/80, I5 68I, nr. 7, p. 7.

84 Kamerstukken II I978/79, I5 68I, nr. 3, p. 4. 
De opsomming van grondrechten in artikel 103 bevat alleen die grondrechten die in de Grondwet op een onvoorwaardelijke manier zijn geformuleerd of die alleen met het oog op bepaalde belangen dan wel op een bepaalde wijze beperkt mogen worden. Zo worden het recht op bescherming van de persoonlijke levenssfeer (artikel Io Grondwet) en het recht op onaantastbaarheid van het lichaam (artikel II Grondwet) niet genoemd. Deze rechten krijgen slechts grondwettelijke bescherming 'behoudens bij of krachtens de wet te stellen beperkingen'. Het niveau van bescherming ligt geheel in handen van de wetgever. Noodwetgeving die mogelijk vergaande beperkingen aan deze rechten oplegt, blijft daarmee binnen de normale grondwettelijke beperkingsclausule zodat een machtiging op grond van artikel 103 overbodig is. ${ }^{85}$

Naast afwijking van een aantal grondrechtenbepalingen uit de Grondwet biedt het tweede lid van artikel I03 ook de mogelijkheid tot afwijking van artikel II3, eerste en derde lid, Grondwet: bepalingen die de bevoegdheid tot berechting van strafbare feiten en tot het opleggen van vrijheidsbenemende straffen exclusief toekennen aan de rechterlijke macht. Hieraan ligt de overweging ten grondslag dat mobiele krijgsraden, niet behorend tot de rechterlijke macht, tijdens een uitzonderingstoestand bevoegd moeten kunnen zijn tot de berechting van plegers van strafbare feiten en tot oplegging van vrijheidsstraffen. ${ }^{86}$

Zoals we in hoofdstuk 5 nog zullen zien, kiest artikel 103 Grondwet ten aanzien van de afwijking van grondrechten een andere benadering dan de noodtoestandsbepalingen uit het EVRM en het IVBPR. Deze sommen namelijk juist de rechten op waarvan niet mag worden afgeweken, de zogenoemde notstandsfeste rechten.

\subsection{De wetgeving ter uitvoering van artikel ro3 Grondwet}

\subsubsection{De Coördinatiewet uitzonderingstoestanden en het uitroepen van een noodtoestand}

Bij de grondwetsherziening van 1983 was een uitvoerige herziening van de Nederlandse noodwetgeving aangekondigd. De nieuwe wetgeving ter uitvoering van artikel I03 heeft echter lang op zich laten wachten. Op 3 april I996 kwamen de Coördinatiewet uitzonderingstoestanden $(\mathrm{Cwu})$, een uitvoeringswet daarvan, alsook een nieuwe Wet buitengewone bevoegdheden burgerlijk gezag (Wet bbbg) en een nieuwe Oorlogswet voor Nederland (OWN) tot stand. ${ }^{87}$ Op I mei 1997 is deze nieuwe wetgeving in werking getreden. De Cwu regelt de instelling, opheffing en het einde van een uitzonderingstoestand, alsmede de overgang van de ene naar de andere uitzonderingstoestand. De wet kent twee, naar zwaarte opklimmende, uitzonderingstoestanden: de beperkte en de algemene noodtoestand. Conform de grondwettelijke eis geschiedt afkondiging van de ene dan wel de andere noodtoestand bij koninklijk besluit, op voordracht van de minister-president (artikel I $\mathrm{Cwu}$ ). Deze eis brengt met zich dat alleen nog de regering bevoegd is tot het afkondigen van een uitzonderingstoestand, andere autoriteiten (bijvoorbeeld militaire)

85 Elzinga, De Lange \& Hoogers 20I4, p. 77I; Kummeling 20I4, p. 272.

86 Kamerstukken II I979/8o, I5 68I, nr. I2, p. I.

87 Stb. I996, nrs. 365-368. Zie voor de totstandkoming van deze wetten: Kamerstukken II I986/87, 20 028, nrs. I-4; Kamerstukken II \& I, 23788 (OWN), 23 789 (Wet bbbg), 23790 (Cwu), 23 79I (Invoeringswet); Handelingen II I994/95, nr. 95, p. 5833-5855. 
mogen dit niet. ${ }^{88}$ Vereist is dat 'buitengewone omstandigheden' deze afkondiging 'noodzakelijk maken'. Zoals in \$ 3.2.2 al is aangegeven wordt dit koninklijk besluit terstond aan de Staten-Generaal medegedeeld, die in verenigde vergadering besluiten of de (beperkte dan wel de algemene) noodtoestand mag voortduren (artikel $2 \mathrm{Cwu}$ ). De opheffing van een noodtoestand kan op twee wijzen geschieden: door een besluit van de Staten-Generaal in verenigde vergadering of bij koninklijk besluit op voordracht van de minister-president (artikel $3 \mathrm{Cwu}$ ). De beperkte noodtoestand eindigt van rechtswege bij het inwerkingtreden van de algemene noodtoestand en vice versa (artikel $4 \mathrm{Cwu}$ ).

\subsubsection{Uitoefening noodbevoegdheden; typen noodbevoegdheden}

Het instellen van een noodtoestand houdt niet automatisch de mogelijkheid tot de toepassing van noodbevoegdheden in. Daartoe is een afzonderlijk koninklijk besluit vereist (artikel $7 \mathrm{Cwu}$ ). Indien de beperkte of de algemene noodtoestand is afgekondigd, worden bij koninklijk besluit (wederom op voordracht van de minister-president) voor heel Nederland of een gedeelte daarvan bepalingen in werking gesteld die voorkomen op twee bij de Cwu behorende lijsten: een lijst A en een lijst B. Van de eerste lijst kunnen bepalingen in werking worden gesteld in het geval dat de beperkte noodtoestand is afgekondigd (artikel 7, eerste lid, Cwu), van de tweede als de algemene noodtoestand is uitgeroepen (artikel 8, eerste lid, $\mathrm{Cwu}$ ). Beide lijsten bevatten een, grotendeels gelijkluidende, opsomming van (nood)bepalingen uit een veertigtal wetten.

Van ongeveer de helft van de op lijsten opgenomen wetten kan overigens niet worden gezegd dat ze in eerste instantie geschreven zijn met het oog op de regulering van buitengewone omstandigheden. Deze wetten bevatten dan ook vaak maar één of een summier aantal bepalingen voor buitengewone omstandigheden. Het gaat dan om de volgende wetten: de Vreemdelingenwet, de Wet veiligheidsregio's, de Comptabiliteitswet, de Kaderwet dienstplicht, de Wet bescherming staatsgeheimen, de Onteigeningswet, de Woningwet, de Luchtvaartwet, de Wet vervoer gevaarlijke stoffen, de Vaarplichtwet, de Binnenvaartwet, de Scheepvaartverkeerswet, de Loodsenwet, de Telecommunicatiewet, de Postwet 2009, de Wet rijonderricht motorrijtuigen 1993, de Wet luchtvaart, de Wegenverkeerswet I994, de Warenwet en de Wet medisch-wetenschappelijk onderzoek met mensen. Voor de andere helft van de op de lijsten A en B figurerende wetten geldt dat zij in hun geheel nadrukkelijker zien op noodsituaties: de Wet buitengewone bevoegdheden burgerlijk gezag (Wet bbbg), de Oorlogswet voor Nederland (OWN), de Noodwet rechtspleging, de Wet verplaatsing bevolking, de Noodwet financieel verkeer, de Wet militaire inundaties, de Inkwartieringswet, de Wet behoud scheepsruimte I939, de Distributiewet, de Hamsterwet, de Vorderingswet, de Prijzennoodwet, de Bodemproductiewet I939, de Noodwet arbeidsvoorziening, de Noodwet voedselvoorziening en de Noodwet geneeskundigen.

Het verschil tussen beide lijsten is dat in lijst B ook bepalingen zijn opgenomen, waarin van de Grondwet wordt afgeweken. Daarbij gaat het om de bepalingen van een viertal wetten, te weten: de hierboven reeds genoemde Wet bbbg (artikel II-28)

88 Kuitert I988, p. I72. De Oorlogswet I899 stond nog toe dat het militair gezag Nederland in staat van beleg kon verklaren. 
en OWN (artikel 24-53) en daarnaast de Mediawet (artikel I74, eerste lid) en de Noodwet rechtspleging (artikel 17 ). De Wet bbbg en de OWN vormen de kern van de Nederlandse noodwetgeving. Onder de OWN concentreren zich de buitengewone bevoegdheden bij de Minister van Defensie en het militair gezag. Onder de Wet bbbg blijven de buitengewone bevoegdheden berusten bij burgerlijke ambten zoals de Commissaris van de Koning en de burgemeester, die deze bevoegdheden slechts uitoefenen voor zover dit naar hun oordeel nodig is met het oog op de handhaving van de openbare orde en veiligheid (artikel 3 Wet bbbg). Met betrekking tot de afwijking van de in artikel ro3, tweede lid, Grondwet genoemde grondrechtenartikelen bevat de Wet bbbg grotendeels dezelfde mogelijkheden als de OWN. Beide wetten verschaffen het burgerlijke respectievelijk militaire gezag buitengewone bevoegdheden voor crisisbeheersing onder buitengewone omstandigheden, zoals:

- het vorderen van inlichtingen en van inzage in bescheiden of andere informatiedragers (artikel 5 Wet bbbg, artikel 9 OWN);

- het ontzeggen van de toegang tot en het gebruik van bepaalde gebouwen, verblijfplaatsen of terreinen (artikel 9 Wet bbbg, artikel ro OWN);

- de beperking van het verblijf in de open lucht (artikel 8 Wet bbbg, artikel II OWN);

- het verbieden van vertoningen en het vorderen van het gebruik over inrichtingen van telecommunicatie (artikel ig OWN);

- het ontruimen van bepaalde gebieden (artikel 2I OWN);

- het onderscheppen of verhinderen van telecommunicatie en het maken van andere inbreuken op het communicatiegeheim zonder rechterlijke machtiging (artikel I4 Wet bbbg, artikel 3I-32 OWN);

- het vrijwel algeheel verbieden van de publicatie van uitingen via de drukpers en van betogingen, van vergaderingen en van andere openbare samenkomsten (artikel II-I3 Wet bbbg, artikel 34-36 OWN);

- het verrichten van onderzoek aan kleding of lichaam en het doen van huiszoekingen zonder voorafgaande rechterlijke machtiging (artikel I5-I6 Wet bbbg, artikel 38-39 OWN); en

- het interneren van bepaalde (groepen van) personen die geacht worden een gevaar voor de staatsveiligheid te vormen (artikel I8-28 Wet bbbg, artikel 44-59 OWN).

De systematiek van de noodwetgeving zoals die in 1996 met de Cwu tot stand is gekomen, is opgezet vanuit de idee van een 'flexibele crisisbeheersing'. ${ }^{89}$ De gedachte daarbij is dat alleen die buitengewone bevoegdheden ter beschikking dienen te komen die door de situatie geboden zijn. Zo is het denkbaar dat bij een ramp van beperkte omvang wordt volstaan met toepassing van buitengewone bevoegdheden uit één of een beperkt aantal op de situatie toegesneden wetten, zoals de Wet veiligheidsregio's, de Wet verplaatsing bevolking en de Noodwet geneeskundigen, zonder dat behoeft te worden overgegaan tot inwerkingstelling van bijvoorbeeld de bepalingen uit de Wet bbbg of OWN die de bevoegdheid verlenen om bepaalde (groepen van) burgers te interneren. Ook bij internationale spanningen laat

$89 \quad$ Kamerstukken II I986/87, 20 028, nrs. I-2, p. 9 en II. 
zich een in zwaarte oplopende schaal denken van buitengewone bevoegdheden die gelijke tred houdt met de ernst van de crisis. Al naar gelang het verloop van de crisis zullen de buitengewone bevoegdheden kunnen worden opgevoerd c.q. teruggebracht: van uitsluitende toepassing van buitengewone bevoegdheden in de sfeer van het goederenvervoer (Vervoersnoodwet) tot het volledige scala van crisisbestrijdingsmiddelen, inclusief de zware bevoegdheden uit de Wet bbbg en de OWN.

\subsubsection{Separate toepassing: noodbevoegdheden buiten de uitzonderingstoestand om}

Het uitgangspunt van een flexibele crisisbeheersing brengt tevens met zich dat het gebruik van buitengewone bevoegdheden niet uitsluitend hoeft plaats te vinden in het kader van een van de twee door de Cwu voorziene uitzonderingstoestanden. Het kan ook daar buitenom gebeuren. Dit wordt wel 'separate toepassing' van noodwetgeving genoemd. Alle op de (bij de Cwu behorende) lijsten A en B voorkomende wetten kennen daartoe een standaardbepaling die voorziet in een procedure voor de inwerkingstelling van één of meer noodbepalingen van de betreffende wet. ${ }^{\circ}$ Die procedure bestaat daarin dat bij koninklijk besluit, op voordracht van de minister-president, wordt kenbaar gemaakt welke bepaling(en) van de wet in werking wordt (worden) gesteld. Daarna wordt onverwijld een voorstel van wet (ook wel verlengingswet genoemd) aan de Tweede Kamer gezonden omtrent het voortduren van die inwerkingstelling. Wordt het voorstel door de Staten-Generaal verworpen, dan wordt (worden) bij koninklijk besluit de aanvankelijk in werking gestelde bepaling(en) onverwijld buiten werking gesteld. In geval van separate toepassing van noodwetgeving mag, evenmin als onder de beperkte noodtoestand, worden afgeweken van de in artikel ro3 genoemde grondwetsbepalingen.

De plicht tot inwerkingstelling bij koninklijk besluit geldt niet voor alle noodbepalingen. Er zijn ook noodregelingen die geheel vormvrij kunnen worden toegepast. In geval van buitengewone omstandigheden kunnen deze buitengewone bevoegdheden direct worden toegepast. Er is geen inwerkingstellings-KB nodig en evenmin is sprake van een noodzaak tot indiening van een verlengingswet. Voorbeelden zijn artikel 175 en 176 Gem.w, artikel I7.I9 Wet milieubeheer, artikel 2 Prijzenwet en artikel 6:2 Wet financieel toezicht. Deze vormvrije noodbepalingen kenmerken zich door de toekenning van een ruime beleids- en beoordelingsvrijheid aan het bestuur. ${ }^{91}$

\subsection{Lokale noodtoestanden: de noodbevoegdheden van de burgemeester}

Ook op gemeentelijk niveau is sprake van een vorm van noodrecht, in de vorm van enkele noodbevoegdheden voor de burgemeester. Artikel 175 Gem.w. regelt het noodbevel, artikel 176 de noodverordening en artikel 176 a regelt de mogelijkheid van toepassing van bestuurlijke ophouding vanwege het groepsgewijs niet-opvolgen van een noodbevel of noodverordening.

90 Zie voor voorbeelden van deze standaardbepaling o.m. art. I Wet bbbg en art. I OWN.

9 I S. Daniëls, 'Commentaar op artikel 103 van de Grondwet', in: E.M.H. Hirsch Ballin \& G. Leenknegt (red.), Artikelsgewijs commentaar op de Grondwet, webeditie 2016 (www.nederlandrechtsstaat. $\mathrm{nl}), \mathrm{p} \cdot 5^{-6}$. 
Artikel 175 Gem.w. omschrijft de situaties waarin de noodbevels- en noodverordeningsbevoegdheid kunnen worden toegepast: 'in geval van oproerige beweging, van andere ernstige wanordelijkheden of van rampen, dan wel bij ernstige vrees voor het ontstaan daarvan'. Dit houdt in dat beide bevoegdheden kunnen worden toegepast bij zowel ernstige wanordelijkheden ter handhaving van de openbare orde als bij rampen ter handhaving van de openbare veiligheid, dan wel een combinatie van beide omstandigheden. ${ }^{92}$ Het begrip 'ramp' moet in artikel 175 Gem.w. op dezelfde wijze worden uitgelegd als in de Wet veiligheidsregio's: 'een zwaar ongeval of een andere gebeurtenis waarbij het leven en de gezondheid van veel personen, het milieu of grote materiële belangen in ernstige mate zijn geschaad of worden bedreigd en waarbij een gecoördineerde inzet van diensten of organisaties van verschillende disciplines is vereist om de dreiging weg te nemen of de schadelijke gevolgen te beperken'. Daarnaast geldt dat de beide noodbevoegdheden alleen kunnen worden toegepast als de gewone bevoegdheden tekortschieten. Dat kan het geval zijn bij kleinschalige, lokale incidenten, zoals gevaar van instorting van gebouwen wegens in de nabijheid aanwezige mijnen, ${ }^{93}$ maar ook bij problemen van nationale of internationale schaal. De (dreigende) ernstige ordeverstoring moet wel concreet en actueel zijn en een acute dreiging of daadwerkelijke aantasting van de openbare orde inhouden. ${ }^{94}$

Artikel 175 en 176 Gem.w. openen voor de burgemeester de mogelijkheid tot het afwijken van wettelijke voorschriften. Er mag echter niet worden afgeweken van voorschriften uit de Grondwet. Dit betekent geenszins dat bij de uitoefening van de burgemeesterlijke noodbevoegdheden geen inbreuken op grondrechten kunnen worden gemaakt. Deze zullen dan evenwel in overeenstemming moeten zijn met de beperkingsclausule die in betreffende grondwetbepaling is opgenomen. ${ }^{95} \mathrm{Het}$ constitutioneelrechtelijke probleem dat zich hierbij voordoet is dat het de vraag is of de artikelen 175 en I76 Gem.w. te beschouwen zijn als wetsbepalingen die specifiek bedoeld zijn om bepaalde grondrechten in te perken. De grondwettelijke doctrine eist namelijk dat het grondrecht wordt ingeperkt door een wetsbepaling die dit specifiek tot doel heeft. Zo is bijvoorbeeld de algemene regelingsbevoegdheid van de gemeenteraad op grond van artikel I49 Gem.w. een onvoldoende specifieke wettelijke basis voor het maken van inbreuken op de persoonlijke levenssfeer. ${ }^{96}$ Bij de herziening van de Gem.w. in 1992 heeft de regering enkele bepalingen van de Grondwet in relatie tot de noodbevoegdheden van artikel 175 en 176 Gem.w. zo geïnterpreteerd, dat beperking toch mogelijk is. Het gebruik van de noodbevoegdheden diende in de ogen van de regering dezelfde doelen als opgenomen in de beperkingsclausules van artikel 6 en 9 Grondwet (het voorkomen van wanordelijkheden, belang van het verkeer). Ook verwees de regering naar het feit dat in de jurisprudentie over artikel 7 Grondwet is erkend dat ook gemeentelijke regelgevers en bestuursorganen beperkingen kunnen aanbrengen op de verspreiding

92 E.T. Brainich, J.G. Brouwer \& A.J. Wierenga, T\&C Openbare orde en veiligheid, commentaar op art. I75 Gem.w., aant. I.

93 ABRvS I4 januari 2009, ECLI:NL:RVS:2009:BG9795, JB 2009/56.

94 Brainich 2004, p. 74; zie ook: J.G. Brouwer \& A.J. Wierenga, 'Toepassing van openbare-ordebevoegdheden in het systeem van het openbare-orderecht', in: E.R. Muller \& J. de Vries c.s. (red.), Burgemeester: Positie, rol en functioneren van de burgemeester, Deventer: Kluwer 20I4, p. I68-I74.

95 Kamerstukken II I975/76, I3 872, nr. 3, p. 2I-22.

96 ABRvS 28 augustus I995, AB I996/205 (Drugspand Venlo). 
van drukwerk en andere vormen van meningsuiting in verband met de handhaving van de openbare orde. ${ }^{97}$ Beperking van verdragsrechtelijk gegarandeerde grondrechten bij noodbevel of noodverordening is eveneens mogelijk. Ook vanuit het perspectief van de EVRM-beperkingsclausules kan zo'n beperking gezien worden als 'bij wet voorzien'. ${ }^{8}$ Desalniettemin hebben zich in het verleden wel juridische discussies over onduidelijkheden voorgedaan, onder meer over de vraag of de noodverordeningsbevoegdheid een voldoende basis zou bieden voor het gelasten van evacuatie van burgers. ${ }^{99}$

In de jurisprudentie van de bestuursrechter is uitgekristalliseerd dat de noodbevels- en noodverordeningsbevoegdheid zich niet lenen om langdurig of structureel ingezet te worden bij een voortdurend ordehandhavingsprobleem als ook reguliere maatregelen in de aanpak daarvan kunnen voorzien. ${ }^{\text {Io }}$ Ook zijn de beide maatregelen op zichzelf tijdelijk van karakter. Een noodbevel richt zicht tot een bepaald individu of een afgebakende groep individuen en de werking ervan vervalt zodra het bevel is opgevolgd. ${ }^{\text {Ior }}$ Is een noodmaatregel vereist die zich richt tot een onbepaald aantal personen, dan is een noodverordening ex artikel 176 het geëigende instrument. De voorschriften in een noodverordening zijn voor herhaalde toepassing vatbaar en kunnen voor een nader aangeduide periode gelden. ${ }^{\mathrm{Io} 2}$ Noodverordeningen vervallen als ze niet in de eerstvolgende gemeenteraadsvergadering worden bekrachtigd (zie artikel I76, derde lid, Gem.w.).

Noodbevelen en noodverordeningen zijn besluiten in de zin van de Algemene wet bestuursrecht en zijn niet uitgezonderd van toetsing door de bestuursrechter. De rechter kan zo nodig in een aan hem voorgelegd concreet geval een oordeel geven over de vraag of sprake was van een noodsituatie of van ernstige vrees voor het ontstaan daarvan en of de getroffen maatregelen proportioneel waren. In de praktijk houdt de toetsing door de bestuursrechter het midden tussen marginale en volle toetsing. Enerzijds overweegt de rechter veelal dat aan de burgemeester beoordelingsvrijheid toekomt en toetst hij of de burgemeester in redelijkheid tot toepassing van het noodbevel of uitvaardiging van de noodverordening kon komen. Maar vervolgens graaft de rechter tamelijk diepgaand of de omstandigheden de toepassing of uitvaardiging legitimeerden. ${ }^{\text {I03 }}$

97 Kamerstukken II I985/86, I9 403, nr. 3, p. I50-I5I; Kamerstukken II I988/89, I9 403, nr. Io, p. 95-IoI. Zie tevens M.A.D.W. de Jong, Orde in beweging. Openbare orde en de persoonlijke vrijheid (diss. Utrecht), Deventer: W.E.J. Tjeenk Willink 2000, p. II5 e.v.

98 EHRM 4 juni 2000, AB 2002/407 en EHRM 4 juni 2002, AB 2003/r9.

99 Zie M.A.D.W. de Jong, H.R.B.M. Kummeling \& M.C. Burkens, Het gebruik van gemeentelijke noodbevoegdheden, Zwolle: W.E.J. Tjeenk Willink I994, p. I38-I47.

Ioo Zie o.m. ABRvS I4 mei I996, ECLI:NL:RVS:I996:AH6359, JB I996/I69.

IoI Brainich, Brouwer \& Wierenga, T\&C Openbare orde en veiligheid, commentaar op art. I75 Gem.w., aant. 3 i.

IO2 Idem, aant. 3g.

I03 Idem, aant. 5 (met verwijzingen naar recente jurisprudentie). 


\section{De toepassing van noodtoestanden en staatsnoodrecht in de praktijk}

\section{I Staatsnoodrecht in onbruik na de Tweede Wereldoorlog}

Het Nederlandse grondwettelijk staatsnoodrecht leidt anno 2016 een vrijwel slapend bestaan. Discussies over het bestaansrecht van het staatsnoodrecht zijn in Nederland vooral gevoerd aan het begin van de twintigste eeuw, na de Eerste Wereldoorlog. Die periode leverde enerzijds de erkenning op van het bestaan van een subjectief (staats)noodrecht, aangezien uit het veranderende karakter van de oorlogvoering voortvloeide dat niet alle mogelijke noodsituaties vooraf voorzienbaar en in objectief noodrecht te vatten waren. Als voorbeeld van het uitoefenen van subjectief staatsnoodrecht mag gelden het uitgevaardigde verbod van gouduitvoer uit 19I4, waarvoor geen enkele wettelijke grondslag was. ${ }^{104}$ Anderzijds vond een enorme uitbreiding van het geschreven noodrecht plaats. Deze uitbreiding zou zich na de Tweede Wereldoorlog voortzetten, parallel aan de groeiende overheidsbemoeienis met het maatschappelijk leven die toen plaatsvond. Met de groei van het aantal beleidsterreinen voor de overheid nam ook de behoefte aan regelingen voor noodsituaties op die terreinen toe. ${ }^{105}$

Aanvankelijk ging die uitbreiding gepaard met een grote versnippering en onduidelijke afstemming, later volgden wetgevingsoperaties om een verduidelijking van de structuur en betere afstemming van de noodwetgeving te bewerkstelligen: de Coördinatiewet uitzonderingstoestanden. Bij de uitbreiding van het geschreven noodrecht werd ernaar gestreefd om zo veel mogelijk garanties voor inbreng van de volksvertegenwoordigende organen op te nemen (onder meer met betrekking tot de besluitvorming over het uitroepen van een uitzonderingstoestand) en om zo lang en zo veel mogelijk vast te houden aan de normale constitutionele ordening en structuren.

Praktijkervaring met het staatsnoodrecht heeft Nederland voornamelijk in en kort na de Tweede Wereldoorlog opgedaan. Dit was toen aanleiding voor een hernieuwde discussie, die zich vooral toespitste op de vraag of ook buiten het in de Grondwet erkende en in grote trekken geregelde speciale recht voor noodtoestanden het bestaan van staatsnoodrecht moest worden aanvaard. Na de periode van rond de Tweede Wereldoorlog is het Nederlandse staatsnoodrecht, althans de wetgeving met betrekking tot het uitroepen van nationale uitzonderingstoestanden als de staat van oorlog of de staat van beleg, in de praktijk niet meer toegepast.

In de jaren zeventig van de vorige eeuw werd Nederland weliswaar enkele malen geconfronteerd met vormen van terrorisme bestaande uit gijzelingsacties en treinkapingen, maar deze vormden indertijd geen aanleiding voor gebruikmaking van regels van staatsnoodrecht. ${ }^{106}$ Hoewel Nederland in recente jaren is geconfronteerd met activiteiten van terroristische groepen van geradicaliseerde moslims (denk aan de zogenoemde 'Hofstadgroep') en met een moordaanslag met een

I04 KB 3I juli I9I4, Stb. I9I4, 333. Een dergelijk verbod werd overigens herhaald in I936 (KB 26 september 1936 , Stb. I936, 52), opnieuw zonder wettelijke grondslag. Zie Elzinga, De Lange \& Hoogers 2014, p. 767.

I05 Brainich I993, p. 87.

Io6 Zie hierover Grotenhuis \& Schat I979, p. 4I8-4I9 en B. de Graaf \& I. Duyvesteyn, Terroristen en hun bestrijders: vroeger en nu, Amsterdam: Boom 2007. 
terroristisch oogmerk (de moord op filmregisseur en columnist Theo van Gogh, in 2004), is dit geen aanleiding geweest om delen van de Nederlandse noodwetgeving in werking te stellen. In antwoord op Kamervragen gaf de regering aan dat de inwendige veiligheid van Nederland door deze gebeurtenissen niet dusdanig in gevaar was dat er reden was voor gebruikmaking van enige van de noodbevoegdheden zoals voorzien in de Nederlandse noodwetgeving. ${ }^{107}$ Op verdere recente ontwikkelingen in het kader van de terrorismebestrijding en ook de financiële crisis ga ik hieronder nog separaat in.

Wel is er sprake van een praktijk waarin op gemeentelijk niveau, door de burgemeester, noodbevoegdheden worden toegepast. Deze praktijk is zo omvangrijk dat die zich binnen het bestek van dit preadvies niet volledig laat beschrijven. ${ }^{\text {108 }}$ Daarnaast is er in recente jaren sprake geweest van een toepassing van de uitzonderingsmogelijkheid van artikel I4, tweede lid, Grondwet: onteigening zonder vooraf vastgestelde schadeloosstelling. Dit deed zich voor op basis van de Deltawet grote rivieren. Dit was een spoedwet die door de wetgever werd vastgesteld naar aanleiding van de dreigende overstromingen in de jaren negentig van de twintigste eeuw door een beperkte bergingscapaciteit van de grote rivieren. Met de spoedwet konden rivierdijkversterkingen snel en zonder al te veel procedurele rompslomp worden uitgevoerd. In artikel 5 van de Deltawet grote rivieren was een regeling opgenomen die onverwijlde inbezitneming van onroerende zaken mogelijk maakte; de schadeloosstelling werd aan de hand van de onteigeningswetsystematiek pas na de inbezitneming vastgesteld. ${ }^{\text {109 }}$

\subsection{De toepassing van staatsnoodrecht in en rond de Tweede Wereldoorlog}

In de jaren I938-I939 bereidde Nederland zich voor op een mogelijke oorlog. Dit ging gepaard met een uitbreiding van de noodwetgeving, met name op economisch terrein. In het kader van de voorbereiding van een oorlogseconomie werden onder meer (nood)wetten tot stand gebracht ter regulering van de goederenstroom, de bodemproductie, de industriële productie, de import en export en de distributie van goederen en levensmiddelen. ${ }^{\text {Io }}$ Sommige van deze wetten kwamen reeds tot stand in afwijking van de normale wetsprocedure. Zij werden in sterk verhoogd tempo behandeld door de Staten-Generaal. Weliswaar werd de wettelijk voorgeschreven wetsprocedure in grote lijnen wel gevolgd, maar er werd afgeweken van

I07 Kamerstukken II 2004/05, 29 754, nr. 6, p. 9-Io. In antwoord op een vraag waarom de regering niet bereid is om vermeende terroristen preventief te detineren antwoordt de regering: 'Het Wetboek van Strafvordering voorziet niet in de mogelijkheid iemand preventief te detineren zonder dat daaraan de verdenking van een strafbaar feit ten grondslag ligt (interneren). Deze wetgeving is in overeenstemming met het EVRM. Op grond van de Coördinatiewet uitzonderingstoestanden en de Wet buitengewone bevoegdheden burgerlijk gezag mag in Nederland wel in tijd van oorlog of in geval van enig andere algemene noodtoestand die het bestaan van het land bedreigt, maar alleen in die gevallen dat de ernst van de situatie deze maatregelen strikt vereist, worden overgegaan tot interneren. Van een dergelijke toestand is geen sprake.'

Io8 Brainich, Brouwer \& Wierenga, T\&C Openbare orde en veiligheid, commentaar op art. 175 Gem.w., aant. I, bevat een overzicht van de situaties in de laatste decennia waarin de gemeentelijke noodbevoegdheden werden toegepast.

Iog T. Peters, 'Commentaar op artikel I4 van de Grondwet', in: E.M.H. Hirsch Ballin \& G. Leenknegt (red.), Artikelsgewijs commentaar op de Grondwet, webeditie 2016 (www.nederlandrechtsstaat.nl).

Brainich I993, p. II3-I38. 
de regels van de reglementen van orde van de Tweede en Eerste Kamer. De procedure kreeg minder inhoud. ${ }^{\text {II }}$

Al snel na het uitbreken van de Tweede Wereldoorlog bleek de ontoereikendheid van alle wettelijke voorzieningen in het licht van de extreme situatie veroorzaakt door de Duitse bezetting van Nederland, het uitwijken van Koningin Wilhelmina en de rest van de regering naar Londen, en het door de Duitsers buiten werking stellen van de Staten-Generaal. Hierdoor ontstond een toestand die om allerlei redenen in strijd was met de Grondwet. Zo konden wetten uiteraard niet meer tot stand komen door de grondwettelijk vereiste samenwerking van regering en Staten-Generaal. Bovendien verbood artikel 2I van de toenmalige Grondwet uitdrukkelijk de verplaatsing van de zetel der regering buiten het rijk. Onder de gegeven omstandigheden restte niets anders dan af te wijken van de Grondwet. Duynstee verwoordde dit in 1946 als volgt: 'Alle conclusies, uit een vooropgezette leer getrokken, zijn bezweken voor de werkelijkheid.' ${ }^{\text {II2 }}$

De regering in Londen stelde zich op het standpunt dat zij zelfstandig bevoegd was tot wetgeving en ging over tot het uitvaardigen van algemene regels in de vorm van koninklijke besluiten, die als ‘wetsbesluiten' werden aangeduid. ${ }^{113}$ In het eerste oorlogsjaar waren louter en alleen het staatshoofd en het kabinet bij de totstandkoming van deze wetsbesluiten betrokken. In de periode juli I942-september 1944 kreeg ook een adviserend orgaan, de Buitengewone Raad van Advies, gelegenheid zijn stem over voorgenomen wetsbesluiten te laten horen, als een soort 'surrogaat' voor de Raad van State. Deze raad bestond echter niet uit Nederlandse volksvertegenwoordigers, maar uitsluitend uit door het kabinet aangewezen leden; de weinige in Londen verblijvende Kamerleden hadden er geen zitting in. Regelmatig is door middel van dergelijke wetsbesluiten een bestaande wet gewijzigd of is zelfs afgeweken van Grondwet. ${ }^{114}$ Voorbeelden van dat laatste waren:

- het besluit van II september 1943, Staatsblad D 6o over de bijzondere staat van beleg; hierbij werd het Nederlandse grondgebied, nadat het door de Duitsers zou zijn ontruimd, in bijzondere staat van beleg verklaard en werd een groot aantal ingrijpende bevoegdheden verleend aan het Militair gezag; ${ }^{115}$

- het Besluit buitengewoon strafrecht van 22 december I943, Staatsblad D 6I, waarbij de strafmaxima gesteld op diverse strafbare feiten uit het Wetboek van Strafrecht en het militair strafrecht aanzienlijk werden verhoogd en - in afwijking van het grondwettelijke verbod op retroactieve strafwetgeving (toenmalig artikel I63 Grondwet; huidig artikel I6 Grondwet) en van artikel I Wetboek van Strafrecht - een nieuw strafbaar feit werd gecreëerd, namelijk het 'opzettelijk gedurende de tijd van den oorlog een ander blootstellen aan opsporing, vervol-

III J.C.E. van den Brandhof, De besluitenwetgeving van de kabinetten De Geer en Gerbrandy (diss. Amsterdam), Deventer: Kluwer I986, p. 7-8 en 43I.

II2 W.J.A.J. Duynstee, 'Staatsnoodrecht', in: Opstellen over hedendaags recht (Feestbundel J.C. van Oven), Leiden: Universitaire Pers I946, p. II7.

II3 Zie Van den Brandhof I986, p. Io9-IIo. Vgl. ook P. Gerbenzon \& N.E. Algra, Voortgangh des rechtes: de ontwikkeling van het Nederlandse recht tegen de achtergrond van de Westeuropese cultuur, Alphen aan den Rijn: Samson H.D. Tjeenk Willink 1987 (6e druk), p. 364.

II4 Bedoeld wordt een afwijking van de Grondwet nog naast de afwijking die reeds plaatsvond door de totstandkoming zonder samenwerking met de Staten-Generaal. Een overzicht van alle uitgevaardigde wetsbesluiten is opgenomen in: Verslag enquêtecommissie regeringsbeleid 1940-I945, deel 5A, 's-Gravenhage i949, p. 895-909. Van den Brandhof I986, p. 33I-349. 
ging, vrijheidsbeneming of -beperking, eenige straf of eenige maatregel door of vanwege de vijand'; ${ }^{\text {ir6 }}$

- het Besluit op de bijzondere gerechtshoven, eveneens van 22 december 1943 , Staatsblad D 62 en het Tribunaalbesluit van 17 september 1944, Staatsblad E Ior, waarbij de berechting van onder meer bovengenoemd delict werd opgedragen aan bijzondere gerechten, bestaande uit ten minste drie juristen en twee militairen, in sommige gevallen zonder de mogelijkheid van een cassatieberoep (een en ander in afwijking van het in de Grondwet verankerde ius de non evocando) en de berechting van andere vormen van collaboratie werd opgedragen aan een soort 'volksrechtbanken', bestaande uit een voorzitter-jurist en twee leken; ;17

- het besluit van 4 september 1944, Staatsblad E 45; dit bepaalde dat dienstplichtigen naar elke plaats konden worden gezonden waar hun aanwezigheid nodig werd geacht in het belang van het koninkrijk, terwijl het toenmalige artikel I92 van de Grondwet voor uitzending naar de overzeese rijksdelen de toestemming van de betrokkenen vereiste.

Ook na de bevrijding is de regering doorgegaan met het uitvaardigen van wetsbesluiten. Er kon nog niet direct een grondwettelijk juiste situatie tot stand komen. Formeel was in september I94I de zittingsduur van de Tweede Kamer verstreken; bovendien was het onder de gegeven omstandigheden ondenkbaar dat de oude Kamers verder zouden kunnen functioneren zonder 'zuivering'. Pas op 20 november 1945 opende de zitting van een 'voorlopige staten-generaal'. ${ }^{\text {I18 }}$

\subsection{Discussies over parlementaire goedkeuring en rechterlijke toetsing van noodmaatregelen na de Tweede Wereldoorlog}

\subsubsection{Geen parlementaire bekrachtiging wetsbesluiten}

Na de oorlogsperiode moest de vraag beantwoord worden of het noodzakelijk was de uitgevaardigde wetsbesluiten alsnog door de door de Grondwet aangewezen wetgevende organen te laten bekrachtigen en of de wetsbesluiten onderworpen waren aan het toetsingsrecht door de rechter. Zowel in de juridische literatuur van kort na de oorlog als in het parlement is over deze vragen een verhit debat gevoerd. ${ }^{\text {II } 9}$

Met betrekking tot het vraagstuk van eventuele bekrachtiging verwierp de Tweede Kamer op II januari I946, na een dagenlang debat, twee moties waarin werd aangedrongen op bekrachtiging van de wetsbesluiten door de formele

II6 Gerbenzon \& Algra I987, p. 367; Van den Brandhof I986, p. 227-236.

II7 Gerbenzon \& Algra I987, p. 367-368; Van den Brandhof I986, p. 246 en 260-265.

II 8 W.J.A.J. Duynstee \& J. Bosmans, Het kabinet Schermerhorn-Drees (Parlementaire geschiedenis van Nederland na I945, deel I), Assen-Amsterdam: Van Gorcum I977, p. 99-Ior.

II9 Zie o.m. Van Dullemen I946, p. 32-34; A.A.L.F. van Dullemen, Staatsnoodrecht en democratie, Alphen aan den Rijn: Samson I947, p. 23; H.L.M. Kramer, 'Autocratie en staatsnoodrecht', NJB I947, p. 320-322; Kranenburg I946, p. 89-9I; Van der Pot I946, p. 442-443; E. Brongersma, 'De grens van het noodrecht', NJB I945, p. 36r-369; E. Brongersma, 'Staatsnoodrecht en democratie', NJB I947, p. 6oI-6Io; Van den Bergh I946, p. 22I-223; Duynstee I946, p. II7-I24. 
wetgever conform de grondwettelijke wetsprocedure. ${ }^{120}$ Aan deze beslissing lagen zowel principiële als praktische overwegingen ten grondslag. Enerzijds had de regering de noodzaak tot bekrachtiging van de wetsbesluiten ontkend, omdat zij op grond van het subjectieve staatsnoodrecht rechtsgeldig waren uitgevaardigd en dus voor hun rechtsgeldigheid geen nadere bekrachtiging bij formele wet vergden. ${ }^{\text {I2I }}$ Anderzijds zou behandeling van één of meer bekrachtigingswetten voor de zeer vele wetsbesluiten die in de oorlogsperiode tot stand waren gebracht zo'n groot beslag op de Staten-Generaal hebben gelegd, dat de praktische uitvoerbaarheid van een dergelijke operatie moeilijk zou zijn geweest in een periode waarin regering en Staten-Generaal ook zeer druk waren met andere dringende zaken. ${ }^{122}$ Ter weerlegging van dit heel praktische argument hadden sommige auteurs (Van Dullemen, Kranenburg) ${ }^{\mathrm{I} 23}$ gesuggereerd om alle wetsbesluiten in één beknopte wet te bekrachtigen, wat de (tijds)belasting van de Staten-Generaal zou verminderen. Andere auteurs (Brongersma, Kramer) ${ }^{124}$ brachten daar tegenin dat een dergelijke bekrachtiging dan slechts een 'formaliteit' zou zijn en geen wezenlijke inhoud zou hebben.

\subsubsection{Rechterlijke toetsing slechts marginaal}

De vraag naar het rechterlijk toetsingsrecht ten aanzien van de wetsbesluiten is in diverse rechterlijke procedures aan de orde gesteld. Nog tijdens de oorlog was het de Engelse rechter die gevraagd werd om een oordeel. Bij KB van 5 augustus I940, Staatsblad Aro, werd de dienstplicht ingevoerd voor Nederlanders in GrootBrittannië, de Verenigde Staten en Canada. Een Nederlander die op grond van dit besluit moest opkomen deserteerde en werd gearresteerd. Hij diende een verzoek in voor een writ of habeas corpus, waarin hij onder meer aanvoerde dat het betreffende KB ongeldig was vanwege strijd met de Nederlandse Grondwet (argumenten: de Kroon is niet bevoegd buiten Nederland te functioneren, de Raad van State is niet gehoord, dienstplicht kan alleen bij wet worden ingesteld; een dienstplichtige kan niet gedwongen worden in het buitenland te dienen en de Nederlandse wet heeft geen extraterritoriale werking). De writ werd echter geweigerd door de Engelse rechter: 'it is not contrary to British constitutional law for the government of an allied state established in England with the consent of the British Government, to issue a decree conscripting it subjects resident in England'. ${ }^{125}$

Na de oorlog overwoog de Bijzondere Raad van Cassatie dat rechterlijke toetsing van de wetsbesluiten geenszins onmogelijk, maar wel begrensd was: geen doelmatigheids- of proportionaliteitstoetsing, alleen een toets of geen misbruik is gemaakt van gezag omdat er feitelijk geen sprake was van een noodsituatie. ${ }^{26} \mathrm{In}$

I20 Handelingen II I945/46, p. I7I-I72, I78, I8I-I84, I90-I9I en 2I7-245. Zie ook Duynstee \& Bosmans I977, p. I43-I45.

I2I Kamerstukken II I945/46, I23, nr. 2, p. 7.

I22 Elzinga, De Lange \& Hoogers 20I4, p. 768.

I23 Kranenburg I946, p. 92; Van Dullemen I947.

I24 E. Brongersma, 'Staatsnoodrecht en democratie', NJB I947, p. 6oI-6Io; H.L.M. Kramer, 'Autocratie en staatsnoodrecht', NJB I947, p. 320-322.

I25 All England Law Reports I942-I, n. 236, aangehaald in Gerbenzon \& Algra 1987, p. 366. Zie ook: P.H.J. Körver, De besluitwetgeving van de Nederlandse regering in Londen in internationaal en staatsrechtelijk perspectief (diss. EUR), Deventer: Kluwer 2004.

I26 Bijzondere raad van Cassatie 5 december I945, Na-Oorlogsche Rechtspraak I946, I50. 
een later arrest - over de verbindendheid van het Besluit bezettingsmaatregelen achtte de Hoge Raad rechterlijke toetsing evenzeer mogelijk, maar beperkte hij de reikwijdte van die toetsing eveneens tot een zeer marginale redelijkheidstoets: alleen als er geen enkele redelijke grond zou zijn geweest voor de getroffen maatregel zou daaraan de geldigheid kunnen ontvallen. ${ }^{127}$ Getoetst aan deze maatstaf kon het Besluit bezettingsmaatregelen volgens de Hoge Raad verbindende kracht niet worden ontzegd. ${ }^{128}$ De rechterlijke toetsingsbevoegdheid van de wetsbesluiten werd dus ten principale erkend, maar wel zeer beperkt uitgelegd.

\subsection{Recente ontwikkelingen: terrorismebestrijding en bankencrisis}

Anders dan sommige andere landen heeft Nederland in de recente geschiedenis niet gereageerd op de veiligheidsbedreiging als gevolg van het transnationale terrorisme door middel van speciale tijdelijke antiterreurwetgeving. Antiterrorismewetgeving is in Nederland hoofdzakelijk geïncorporeerd in het normale Wetboek van Strafrecht en het Wetboek van Strafvordering als resultaat van de Wet terroristische misdrijven (2004), de Wet opsporing en vervolging terroristische misdrijven (2006), de Wet afgeschermde getuigen (2006) en de Wet strafbaarstelling deelname en meewerken aan training voor terrorisme (2009). ${ }^{129}$ Vanwege de soms vergaande inbreuken op mensenrechten die uit de betreffende wetten - en ook uit een aantal andere wetten op het terrein van de openbareordehandhaving en op het terrein van het financieel verkeer (dat laatste in verband met de bankencrisis) - voortvloeien, spreekt Kummeling in zijn NJV-preadvies van 2014 over 'sluipend noodrecht'. ${ }^{130}$ Bevoegdheden die wat betreft hun impact voor de uitoefening van fundamentele rechten en vrijheden én wat betreft hun ingrijpen in de normale bevoegdhedentoedelingssystematiek niet onderdoen voor noodmaatregelen, zijn in de afgelopen decennia in Nederland deel gaan uitmaken van het normale rechtsstelsel.

Hier lijkt Nederland enigszins af te wijken van de internationale trend zoals beschreven in $\$ \mathbf{2 . 5 . 4}$ hierboven. Het is niet de tijdelijke noodwetgeving die blijvende sporen achterlaat in het normale rechtssysteem, het normale rechtssysteem wordt voorafgaand aan eventuele toepassing van noodwetgeving reeds zodanig aangepast dat de toepassing van die noodwetgeving niet meer aan de orde komt. De benodigde bevoegdheden zijn reeds op permanente basis gecreëerd binnen

I27 HR 30 oktober I946, NJ I946, 737 (Van Andel-Gemeente Gorinchem).

I28 Vele lagere rechters en bijzondere gerechtshoven oordeelden in uitspraken gewezen voor dit HR-arrest dat rechterlijke toetsing van de wetsbesluiten geheel was uitgesloten. Zie daarover Van Dullemen 1947, p. 29 en diverse vonnissen van de Rechtbank Rotterdam, nl.: 24 december I995, NJ I946, 56; 28 maart I946, NJ I946, 215; I8 september 1946, NJ I946, 727 en 24 september I946, NJ 1946, 487. Rechterlijke toetsing van beslissingen en verordeningen van plaatselijke autoriteiten die gebaseerd waren op een subjectief noodrecht vond ook plaats. De uitkomst was dat ook op lokaal niveau een beroep van de autoriteiten op subjectief noodrecht werd erkend. Zie HR 25 januari 1952, NJ 1953, 5I (Commissie goederen NSB'ers Franeker); Hof Arnhem 4 juli I95I, NJ I952, 53 (ambtenaar burgerlijke stand). Het meest bekend is HR I5 februari I952, NJ I953 52 (burgemeester van Maurik), over de boeteoplegging door een burgemeester aan een zwarthandelaar onder omstandigheden waarin het contact met de gerechtelijke autoriteiten verbroken was.

I29 Zie over deze wetsvoorstellen o.m. P.H.P.H.M.C. van Kempen \& J. Van de Voort, Nederlandse antiterrorismeregelgeving getoetst aan fundamentele rechten. Een analyse met meer bijzonder aandacht voor het EVRM, Nijmegen: WODC 2010.

I30 Kummeling 20I4, p. 282-29I. 
het normale rechtsstelsel. Het Nederlandse straf- en strafvorderingsrecht geeft sowieso in vergelijking met sommige andere landen al een hoop ruimte aan de opsporingsautoriteiten. Waar in andere landen specifieke noodwetgeving of tijdelijke antiterrorismewetgeving nodig is om bijvoorbeeld de periode van inverzekeringstelling van (terrorisme)verdachten te kunnen oprekken, omdat het normale rechtsstelsel voorschrijft dat die maximaal 36 of 48 uur mag zijn, ligt in Nederland die termijn sowieso al op 87 uur. Nederland kent bijvoorbeeld ook niet, zoals België, een absoluut geformuleerd wettelijk verbod om tussen 2 I.00 en 5.00 uur huiszoekingen te verrichten (al voor de aanslagen in Brussel in maart 2016 stelde de Belgische regering voor dit verbod te schrappen voor terrorismeonderzoeken). ${ }^{131}$

Naast deze ontwikkelingen op strafrechtelijk en strafvorderlijk terrein valt op dat in Nederland bevoegdhedenverschuivingen die onderdeel uitmaken van het contraterrorismebeleid op een laag niveau worden geregeld. In $\$ 2.5$.I vermeldde ik reeds de doorzettingsmacht van de Minister van Veiligheid en Justitie die bij klein $\mathrm{KB}$ werd geregeld en nooit in een wet werd bevestigd. Een ander voorbeeld is de Regeling bijstand bestrijding luchtvaartterrorisme. ${ }^{132}$ Deze ministeriële regeling schept in essentie de bevoegdheid om een civiel vliegtuig uit de lucht te schieten, indien dat zich zo gedraagt 'dat het vermoeden rijst dat het mogelijk gebruikt wordt als een middel voor het plegen van een terroristisch misdrijf'. De regeling is gebaseerd op artikel 59 Politiewet, een artikel dat regelt dat in bepaalde situaties de krijgsmacht bijstand kan verlenen bij de uitoefening van de politietaken. Ook hier is deze wettelijke basis bekritiseerd en is terecht de vraag opgeworpen of het constitutioneel-rechtelijk in de haak is dat het verlenen van de bevoegdheid tot het maken van een inbreuk op het recht op leven van een aanzienlijke groep burgers geschiedt bij ministeriële regeling. ${ }^{133}$ Leert het Fluoriderings-arrest ${ }^{134}$ ons niet dat voor overheidsoptreden dat ingrijpende consequenties heeft voor de persoonlijke levenssfeer van burgers een formeel-wettelijke basis vereist is?

Wat betreft de (nood)maatregelen genomen in verband met de banken- en schuldencrisis wees ik in $\$$ 2.5.I al op de Interventiewet uit 2012 en de manier waarop deze wet zeer ingrijpende maatregelen heeft ingebed in het normale rechtsstelsel buiten het kader van de noodwetgeving. Met betrekking tot de ingrepen die in de jaren 2008-2009 plaatsvonden in het financieel stelsel is in het parlement en daarbuiten wel de vraag gesteld waarom op dat moment geen gebruik werd gemaakt van de noodprocedure van artikel 97 Comptabiliteitswet $(\mathrm{Cw})$. In beginsel maakt artikel $34 \mathrm{Cw}$ staatsovername van bijvoorbeeld delen van banken om de stabiliteit van het financiële stelsel te garanderen reeds mogelijk, zij het dat zo'n maatregel dan 30 dagen moet worden 'voorgehangen' bij de Staten-Generaal. Artikel 97 biedt echter de mogelijkheid om van dat vereiste af te wijken. Er moet dan wel, zoals bij alle separate toepassing van noodwetgeving het geval is, bekendmaking van de maatregel bij koninklijk besluit plaatsvinden en er moet onverwijld een ver-

I3I Art. 7 Algemene wet binnentreden stelt dat de hoofdregel is dat tussen middernacht en 6 uur 's ochtends niet wordt binnengetreden zonder toestemming van de bewoner, maar dat in geval van een dringende noodzaak de rechter een machtiging kan geven om ook's nachts een huiszoeking te verrichten.

I32 Stcrt. 29 april 2005, nr. 83, p. I7.

I33 Zie R. Nehmelman, 'License to kill? Over de rechtmatigheid van een extreme anti-terrorismemaatregel', NJCM-Bulletin 2007, p. 972-983.

I34 HR 22 juni I973, NJ I973, 386. 
lengingswetsvoorstel bij de Tweede Kamer worden ingediend. Waarom maakte de Minister van Financiën geen gebruik van deze (nood)wettelijke mogelijkheid? Het antwoord van de minister was dat hij meende dat deze noodprocedure slechts gehanteerd zou mogen worden als het land onbestuurbaar is of dreigt te worden. ${ }^{135}$ Zijn antwoord gaf blijk van onbekendheid ten departemente met de hierboven beschreven ontwikkeling die zich rondom de criteria voor inzet van noodbevoegdheden in de twintigste eeuw heeft voorgedaan. Terecht hebben Diamant en Van Emmerik eerder betoogd dat ook de economische veiligheid als vitaal staatsbelang reden kan vormen voor het gebruik van de relevante noodwettelijke bevoegdheden. Die hebben als belangrijk voordeel dat ze een vast mechanisme kennen voor het realiseren van betrokkenheid van de volksvertegenwoordiging. ${ }^{136}$

In juli 2016 publiceerde het College voor de Rechten van de Mens zijn jaarrapportage Mensenrechten in Nederland 2015. Deze bevat de volgende schets van recente ontwikkelingen op het terrein van de terrorismebestrijding:

'De essentie van contra-terrorismebeleid is het voorkomen van terroristische aanslagen. Overheidsinterventies worden daarom steeds meer ingezet naar aanleiding van uitingen, indicaties en gedragingen die kunnen wijzen op een mogelijke terreurdaad in de toekomst. Daarbij tekent zich het volgende patroon af. In de eerste plaats is de definitie van strafbare feiten opgerekt door allerhande voorbereidingshandelingen strafbaar te stellen en daarvoor ook voorlopige hechtenis toe te staan, bijvoorbeeld het bijeenbrengen van voorwerpen waarmee een aanslag zou kunnen worden gepleegd. Hierdoor is vrijheidsbeneming mogelijk voor minder ernstige vormen van veiligheidsbedreiging. Om die verruimde strafbaarstellingen heen wordt vervolgens als het ware een ring gelegd van bestuurlijke maatregelen met een vrijheidsbeperkend karakter. Die bestuurlijke maatregelen zijn dan toepasbaar in die gevallen waarin nog geen sprake is van strafbaar handelen of voorbereiding van strafbare feiten. Als gevolg hiervan kan vrijheidsbeperkende overheidsinterventie al aan de orde zijn terwijl een daadwerkelijke aantasting van de veiligheid nog ver weg is. ${ }^{\mathrm{I} 37}$

De jaarrapportage van het College laat ook zien wat voor type bestuurlijke terrorismebestrijdingsmaatregelen de laatste jaren zijn en worden bediscussieerd. In de eerste plaats gaat het om reis- en verblijfsbeperkingen: het innemen van paspoorten om uitreizen naar gebieden waar terreurgroepen het voor het zeggen hebben te voorkomen, het intrekken van het Nederlanderschap om terugkeer op Nederlands grondgebied van uitgereisde (vermoede) foreign fighters tegen te gaan (aan intrekking van het Nederlanderschap is plaatsing op een lijst van ongewenste vreemdelingen gekoppeld). Ook wordt gestreefd naar inperking van de bewegingsvrijheid van personen die op grond van hun gedragingen in verband kunnen worden gebracht met terroristische activiteiten of de ondersteuning daarvan door het instellen van een meldplicht, het opleggen van een persoonsverbod of een gebiedsverbod, bijvoorbeeld een verbod het Binnenhof te betreden of in de buurt

I35 Handelingen II 2008/o9, p. II-743.

I36 M. Diamant \& M.L. van Emmerik, 'Parlementair budgetrecht onder vuur?', NJB 20II, p. I9431948. Zie tevens: M. Diamant \& M.L. van Emmerik, 'Het Nederlandse budgetrecht in Europees perspectief', TVCR 2013, p. 95-I00.

I37 College voor de Rechten van de Mens, Mensenrechten in Nederland 2015, Utrecht 20I6, p. 37. 
van bepaalde politici te komen, of een verbod om in de buurt van de landsgrenzen te komen. ${ }^{1{ }^{8}}$ Vanwege het ingrijpende karakter van deze bestuurlijke bevoegdheden is in het wetsvoorstel dat beoogt deze mogelijk te maken een horizonbepaling opgenomen die maakt dat de wet na vijf jaar vervalt. ${ }^{139}$ Hier zien we dus in zekere zin een staatsnoodrechtelijk principe terug.

Naast die bestuurlijke maatregelen is in het kader van de terrorismebestrijding en ook de cybersecurity sprake van een roep om ruimere telecommunicatie- en dataonderscheppingsbevoegdheden voor de inlichtingen- en veiligheidsdiensten. ${ }^{\mathrm{I} 0}$

\section{$5 \quad$ Mensenrechtelijke grenzen aan noodtoestanden en noodmaatregelen}

\section{I Artikel I5 EVRM en artikel 4 IVBPR}

Artikel I5 EVRM en het qua tekst vrijwel identieke artikel 4 IVBPR stellen grenzen aan het gebruik van noodrecht dat maatregelen bevat of autoriseert die afwijken van de normale grondrechtenbescherming. ${ }^{14 \mathrm{I}}$ Uit beide artikelen kunnen zeven eisen worden afgeleid: (a) het uitroepen van een grondrechtenopschortende noodtoestand is slechts toegestaan in geval van een crisissituatie die dermate ernstig is dat het voortbestaan van de natie erdoor bedreigd wordt (een 'algemene noodtoestand die het bestaan van het land bedreigt'); ${ }^{142}$ (b) de grondrechtenopschortende noodtoestand moet officieel worden afgekondigd; (c) grondrechtenopschortende noodmaatregelen zijn slechts gerechtvaardigd indien zij strikt noodzakelijk zijn en in een redelijke verhouding staan tot het doel waartoe zij dienen, namelijk de bestrijding van de crisissituatie; (d) het treffen van grondrechtenopschortende noodmaatregelen mag niet geschieden op willekeurige of discriminatoire gronden; (e) bepaalde grondrechten - de al eerder genoemde notstandsfeste rechten -

I38 Idem, p. 25-3I.

I39 Wetsvoorstel Tijdelijke wet bestuurlijke maatregelen terrorismebestrijding, Kamerstukken II 20I5/I6, 34 359, nrs. I-5.

I40 Zie College voor de Rechten van de Mens, Advies Conceptwetsvoorstel Wet op de inlichtingen en veiligheidsdiensten 20xx, Utrecht 3I augustus 2015. Vgl. ook de Reactie van de CTIVD op het conceptwetsvoorstel Wet op de inlichtingen- en veiligheidsdiensten 2oXX, Den Haag 26 augustus 2015 en J.P. Loof, J. Uzman e.a., Het mensenrechtenkader voor het Nederlandse stelsel van toezicht op de inlichtingen- en veiligheidsdiensten, Universiteit Leiden, augustus 2015, raadpleegbaar via www. ctivd.nl.

I4I Art. I5 EVRM luidt: (I) In tijd van oorlog of in geval van enig andere algemene noodtoestand die het bestaan van het land bedreigt, kan iedere Hoge Verdragsluitende Partij maatregelen nemen die afwijken van zijn verplichtingen ingevolge dit Verdrag, voor zover de ernst van de situatie deze maatregelen strikt vereist en op voorwaarde dat deze niet in strijd zijn met andere verplichtingen die voortvloeien uit het internationale recht. (2) De voorgaande bepaling staat geen enkele afwijking toe van Artikel 2, behalve ingeval van dood als gevolg van rechtmatige oorlogshandelingen, en van de Artikelen 3, 4 (eerste lid), en 7. (3) Elke Hoge Verdragsluitende Partij die gebruik maakt van dit recht om af te wijken, moet de Secretaris-Generaal van de Raad van Europa volledig op de hoogte houden van de genomen maatregelen en van de beweegredenen daarvoor. Zij moet de Secretaris-Generaal van de Raad van Europa eveneens in kennis stellen van de datum waarop deze maatregelen hebben opgehouden van kracht te zijn en de bepalingen van het Verdrag opnieuw volledig worden toegepast.

I42 In de Nederlandse vertaling van art. I5 EVRM wordt het woord noodtoestand gebruikt als aanduiding voor feitelijke omstandigheden, niet als aanduiding voor een rechtsregime. Zie mijn eerdere opmerkingen in $\$ \mathbf{2 . 2}$. 
kunnen nimmer worden opgeschort en mogen derhalve onder geen enkele omstandigheid verder worden ingeperkt dan is toegestaan op grond van de normale beperkingsclausule (zo die bij het betreffende recht is opgenomen); (f) de opschorting van bepaalde grondrechten mag geen schending opleveren van andere internationaalrechtelijke verplichtingen die op de betreffende staat rusten (denk aan verplichtingen op basis van ius cogens, internationaal gewoonterecht, internationaal humanitair recht); ( $\mathrm{g}$ ) opschorting van bepaalde grondrechten is pas toegestaan na internationale notificatie aan de secretaris-generaal van de Raad van Europa en de VN. ${ }^{143}$

Ten aanzien van een aantal van deze eisen is een wat diepere analyse op haar plaats. Deze volgt in de onderstaande paragrafen.

\subsection{De ernst van de noodsituatie of veiligheidsbedreiging}

Vooral in de vroege jurisprudentie van het EHRM (Lawless-arrest uit I96I) en de voormalige Europese Commissie voor de Rechten van de Mens (Greek Case uit 1969) is getracht een nadere aanduiding te geven van de mate van ernst waaraan een crisissituatie moet voldoen, wil deze aangemerkt kunnen worden als een 'algemene noodtoestand die het bestaan van het land bedreigt' in de zin van artikel I5 EVRM. Er moet sprake zijn van een 'exceptional situation of crisis or emergency which affects the whole population and constitutes a threat to the organised life of the community'. ${ }^{\text {I44 }}$ Deze noodsituatie moet reeds zijn ontstaan of onvermijdelijk ophanden zijn. Van de bedreiging van 'the organised life of the community' kan sprake zijn indien de territoriale integriteit van het land of de fysieke integriteit van de bevolking wordt bedreigd, maar ook indien de staatsorganen die ten dienste staan van het welzijn van de bevolking en aan de bescherming van hun individuele rechten en vrijheden zodanig ernstig in hun functioneren worden bedreigd dat het uitvoeren van hun taak onmogelijk wordt. Dit neemt overigens niet weg dat de crisissituatie in geografische zin beperkt kan zijn tot een deel van het land. Ook moet de crisissituatie zodanig zijn dat de normale mogelijkheden om grondrechtenuitoefening te beperken onvoldoende ruimte bieden aan de autoriteiten om de crisis de baas te worden.

Niettegenstaande de poging tot verdere definiëring van de term 'algemene noodtoestand' uit artikel I5 EVRM, geeft de jurisprudentie van het EHRM weinig echte duidelijkheid. Voornaamste oorzaak is het feit dat het Hof geneigd is om verdragsstaten ten aanzien van de vraag of sprake is van zo'n algemene noodtoestand een zeer ruime margin of appreciation te laten. Het komt er in de praktijk op neer dat het Hof zich vrijwel zonder commentaar conformeert aan de verklaringen en opvattingen over het bestaan van een noodsituatie zoals naar voren gebracht door de betreffende regering, indien het Hof de indruk heeft dat deze regering te goeder trouw handelde. ${ }^{\mathrm{I} 5}$ Het duidelijkste voorbeeld hiervan is het arrest A en anderen/ Verenigd Koninkrijk uit 2009. Hierin accepteerde het Hof de aanwezigheid van een

I43 Zie art. I5, derde lid, EVRM en art. 4, derde lid, IVBPR.

I44 EHRM r juli ig6r, Series A Vol. 3 (Lawless/Ierland), \$ 22.

I45 Zie voor een uitvoerige analyse: Loof 2005, p. 389-424 en iets beknopter J.P. Loof, 'On emergencyproof human rights and emergency-proof human rights procedures', in: A. Ellian \& G. Molier, The State of Exception and Militant Democracy in a Time of Terror, Dordrecht: Republic of Letters Publishing 20I2, p. I50-I58. 
'algemene noodtoestand' in het Verenigd Koninkrijk vanwege de veronderstelde terrorismedreiging direct na de 9/II-aanslagen in de Verenigde Staten, hoewel er in die periode nog geen sprake was van feitelijke terreuracties (die zouden vier jaar later wel volgen). ${ }^{\mathrm{I}}{ }^{6} \mathrm{Het}$ Hof gaf in dit arrest ook expliciet aan dat zo'n noodsituatie niet per definitie een tijdelijke situatie is. ${ }^{\mathrm{I} 77} \mathrm{Op}$ het moment dat geaccepteerd wordt dat de enkele dreiging van terrorisme een noodsituatie kan opleveren, kan het Hof ook weinig anders. Bij de dreiging van terrorisme valt moeilijk een duidelijk begin- of eindpunt te markeren. Informatie over dergelijke dreiging zal doorgaans afkomstig zijn van inlichtingen- en veiligheidsdiensten en dus niet of nauwelijks te controleren zijn door rechterlijke instanties, laat staan door een internationaal hof als het EHRM.

\subsection{Sommige fundamentele rechten zijn niet-opschortbaar}

Op grond van het tweede lid van artikel I5 EVRM en van artikel 4 IVBPR zijn bepaalde fundamentele rechten niet-opschortbaar (notstandsfest). Artikel I5 EVRM noemt er vier: het recht op leven, het verbod van foltering en onmenselijke of vernederende behandeling, het verbod van slavernij en dwangarbeid en het verbod op strafwetgeving met terugwerkende kracht (nullum crimen nulla poena-beginsel). Protocol No. 13 bij het EVRM voegt daar het verbod op oplegging van de doodstraf aan toe. Protocol No. 7 kent aan het ne bis in idem-beginsel een notstandsfeste status toe.

Hoewel er in de afgelopen jaren de nodige druk is uitgeoefend op het EHRM om in het licht van de terrorismedreiging de maatstaven ten aanzien van de notstandsfeste rechten bij te stellen, met name waar het gaat om het verbod van refoulement dat door het Hof als onderdeel van het folterverbod wordt aangemerkt, heeft het Hof de rug op dit punt recht gehouden. ${ }^{148}$ Bovendien worden opgesomde notstandsfeste rechten door het EHRM ruim uitgelegd. Allerhande negatieve en positieve verplichtingen worden als inherent aan deze rechten beschouwd: de verplichting tot zorg voor voldoende voedsel en medische hulp voor gedetineerden, ${ }^{\mathrm{I} 9}$ de verplichting tot het treffen van adequate voorzorgsmaatregelen om onnodige slachtoffers te voorkomen bij het met geweld optreden tegen terroristische organisaties ${ }^{150}$ en de verplichting tot het verrichten van een zorgvuldig, transparant, onafhankelijk en onpartijdig onderzoek indien geklaagd wordt over schending van het recht op leven of het verbod van foltering. ${ }^{151}$

In artikel 4 IVBPR is de lijst niet-opschortbare rechten nog wat langer. Naast de rechten die artikel I5 EVRM noemt, komen we daar ook het verbod op gevangenneming bij wanprestatie, het recht om als persoon voor de wet te worden erkend en de vrijheid van gedachte, geweten en godsdienst tegen. Dat laatste recht

I46 EHRM I9 februari 2009, nr. 3455/05 (A e.a./VK).

I47 Idem, § I78.

I48 Zie o.m. EHRM (GC) 28 februari 2008, nr. 37201/o6 (Saadi/Italië); EHRM 2 december 2009, nr. $19576 / 08$ (Daoudi/Frankrijk).

I49 O.m. EHRM I3 juni 2002, nr. 3836r/97 (Anguelova/Bulgarije).

I50 O.m. EHRM 27 september I995, Series A Vol. 324 (McCann e.a./VK); EHRM 28 juli I998, nr. 238I8/94 (Ergi/Turkije); EHRM 20 mei I999, nr. 21594/93 (Ogur/Turkije); EHRM 20 december 20II, nr. I8299/03 en 273II/03 (Finogenov e.a.|Rusland).

I5I O.m. EHRM (GC) 24 maart 20II, nr. 3458/02 (Guliani en Gaggio/Italië); EHRM I8 december 20I2, nrs. 2944/06, 8300/07, 42509/10, 50184/07 en 332/08 (Aslakhanova e.a./Rusland). 
mag dus niet vergaander worden ingeperkt dan op grond van de in het tweede lid van artikel I9 IVBPR opgenomen beperkingsclausule is toegestaan. In de praktijk betekent dit dat de bescherming van het zogenoemde 'forum internum', het gedachtengoed, absoluut is. De manier waarop uiting wordt gegeven aan geweten of godsdienst kan wel worden ingeperkt.

Van belang is ook dat het VN-Mensenrechtencomité in General Comment No. 29 uit $200 \mathrm{I}^{\mathrm{I5} 2}$ de categorie niet-opschortbare rechten nog wat verder oprekt. Het Comité legt daaraan kort gezegd drie redeneringen ten grondslag: (a) de niet-opschortbaarheid wordt afgeleid uit het essentiële belang voor of de nauwe samenhang met expliciet in het tweede lid van artikel 4 als notstandsfest aangemerkte rechten; (b) de niet-opschortbaarheid wordt afgeleid uit de constitutieve systematiek of de interne structuur van het IVBPR; (c) de niet-opschortbaarheid wordt afgeleid uit normen van ius cogens of humanitair recht. Bij deze laatste redenering hanteert het Comité het principe dat bepaalde beginselen waarvan op grond van regels van humanitair recht zelfs tijdens oorlogen of andere gewapende conflicten niet afgeweken mag worden, aangenomen moet worden dat er tijdens minder ernstige crises (waarin de regels van het humanitaire recht niet van toepassing zijn) eveneens niet van mag worden afgeweken. ${ }^{153}$

De belangrijkste rechten die op deze wijze een 'afgeleide' notstandsfeste status hebben verworven zijn het recht op een effectief rechtsmiddel bij vermeende schending van mensenrechten en als species daarvan het recht van habeas corpus en daarnaast het recht op een eerlijk proces in vrijwel al zijn elementen. Slechts aan een paar onderdelen van dit recht kan in een bepaalde mate afbreuk worden gedaan, te weten de openbaarheid van de berechting, de termijn waarbinnen de berechting plaatsvindt en de 'equality of arms' bij opvoering en ondervraging van getuigen. Zowel uit Concluding observations van het VN-Mensenrechtencomité als uit jurisprudentie van het EHRM kan worden afgeleid dat het recht op berechting door een onafhankelijk en onpartijdig tribunaal (als onderdeel van het recht op een eerlijk proces), zelfs in geval van een uitgeroepen noodtoestand, geen ruimte laat voor berechting van burgers door militaire gerechten of voor deelname door militairen aan de civiele rechtspraak. ${ }^{154}$

Ten aanzien van het recht van habeas corpus kan uit de EHRM-jurisprudentie, hoewel het Straatsburgse Hof niet refereert aan enige notstandfeste status voor dit recht, worden afgeleid dat ook tijdens een noodtoestand een gearresteerde persoon binnen een termijn van tussen de acht en tien dagen moet worden voorgeleid aan een rechter voor een toets op rechtmatigheid van het voortzetten van de detentie. ${ }^{155} \mathrm{Als}$ geen sprake is van een noodtoestand, zo bleek uit het al eerder aangehaalde arrest Brogan e.a./VK, is een termijn van vier dagen en zestien uur reeds te lang.

I52 VN doc. CCPR/C/2I/Rev.I/Add.II.

I53 Loof 2005, p. 528-550.

I54 Loof 2005, p. 567.

I55 EHRM 22 april I993, Series A Vol. 258-B (Brannigan en McBride/VK): een termijn van 7 dagen voordat voorgeleiding plaatsvindt, kan nog door de beugel; EHRM I7 september 2003, nr. 4I478/98 (Nuray Sen/Turkije): een termijn van II dagen is te lang. 


\subsection{Een centrale rol voor de proportionaliteits- en subsidiariteitstoets}

In de jurisprudentie van het EHRM en het VN-Mensenrechtencomité speelt de eis dat grondrechtenopschortende noodmaatregelen slechts zijn toegestaan 'voor zover de ernst van de situatie deze maatregelen strikt vereist' een centrale rol. Dit 'strikt vereist'-criterium omvat zowel een toets op proportionaliteit (staat de maatregel in een redelijke verhouding en is die echt noodzakelijk met het oog op de met de maatregel nagestreefde doelen?). Grondrechtenopschortende noodmaatregelen moeten een duidelijk verband hebben met de feiten van de crisissituatie en daarmee in een redelijke verhouding staan, de indringendheid van de noodmaatregelen moet 'meebewegen' met de omvang en ernst van de crisissituatie.

De eis van proportionaliteit heeft een duidelijke relatie met de principiële tijdelijkheid van de grondrechtenopschortende noodtoestand. Met name het VNMensenrechtencomité onderstreept dat noodmaatregelen zo spoedig als mogelijk dienen te eindigen nadat de crisissituatie voorbij is. ${ }^{156}$ Daarnaast kan juist het tijdelijke karakter van een noodmaatregel maken dat deze, ondanks de omvangrijke grondrechteninbreuk die eruit voortvloeit, toch niet disproportioneel is. ${ }^{157}$

In de EHRM-jurisprudentie is opvallend dat waar de toets ten aanzien van de vraag of sprake was van een algemene noodtoestand zeer marginaal is, de toets op de noodzakelijkheid en proportionaliteit van de getroffen noodmaatregelen indringender aan het worden is. Weliswaar onderstreept het Hof dat ook op dit punt aan de staten een margin of appreciation moet worden gelaten, dat ten aanzien van de noodzaak van noodmaatregelen de primaire beoordeling ligt bij de rechterlijke instanties op nationaal niveau en dat er eigenlijk alleen ruimte is voor een andersluidend Straatsburgs oordeel als de nationale rechter de EHRM-uitleg van artikel I5 EVRM geheel onjuist heeft geïnterpreteerd of toegepast, ${ }^{158}$ maar bij de beoordeling van de proportionaliteit van de noodmaatregelen is het eigenlijk veeleer 'business as usual'. ${ }^{159}$ Immers, de proportionaliteitstoets vormt in zeer veel arresten van het EHRM, ook als het gaat om inbreuken die getoetst worden aan de gewone beperkingsclausules, de kern van de uitspraak. In het arrest A en anderen/ VK, dat betrekking heeft op de Britse noodmaatregelen ingevoerd na 9/11, neemt het Hof zelfs - zij het in navolging van de Britse rechter - de doelmatigheid van de maatregelen mee in zijn proportionaliteitsbeoordeling en komt het tot het oordeel dat die maatregelen niet-proportioneel en discriminatoir waren. ${ }^{160}$

I56 VN-Mensenrechtencomité, General Comment No. 29, § 2.

I57 De Lange 2005, p. I32.

I58 EHRM ig februari 2009, nr. 3455/05 (A e.a./VK), § I74.

I59 Loof 20I2, p. I56.

I6o EHRM I9 februari 2009, nr. 3455/05 (A e.a./VK), § I82-I9o. Mijn analyse van dit arrest verschilt van die van Kummeling 20I4, p. 27I, die op dit punt de gedachten van B. van der Sloot, 'Langs lijnen van geleidelijkheid: een jurisprudentieanalyse van artikel I5 EVRM', NTM/NJCM-Bull. 20I2, p. 2I2 volgt. 


\section{Conclusies: een knelpuntenanalyse en enkele aanbevelingen}

\section{I Terug naar de probleemstelling}

In het voorgaande is de vormgeving van het recht inzake noodtoestanden in het Nederlandse publiekrecht geschetst. We hebben gezien hoe het uitroepen van een noodtoestand of het gebruikmaken van noodbevoegdheden is geregeld, wat de juridische consequenties van inwerkingtreding van een uitzonderingstoestand zijn, hoe er ook buiten een noodtoestand kan worden overgegaan tot toepassing van noodrechtelijke bevoegdheden en op welke wijze er controle wordt uitgeoefend door parlement en/of rechter op de uitoefening van noodbevoegdheden en het tot stand brengen van noodbesluiten. We hebben tevens beschouwd welke ruimte er grondwettelijk en verdragsrechtelijk is om over te gaan tot opschorting van de normale mensenrechtenbescherming, met welke veiligheidsbedreigingen we vandaag de dag te maken hebben en over welke type van (nieuwe) bevoegdheden wordt gesproken om die veiligheidsbedreigingen het hoofd te bieden.

Dit brengt ons bij het antwoord op de centrale vraag van dit preadvies: voldoet het noodrecht in het licht van de hedendaagse veiligheidsbedreigingen, is er behoefte aan een ander type nood- of uitzonderingstoestand en hoe zou die er dan uit moeten zien? Natuurlijk moet een antwoord volgen op die vraag, maar het onderzoek voor dit preadvies heeft ook nog enige andere knelpunten en juridische ontwikkelingen aan het licht gebracht. Ook die krijgen in de onderstaande paragrafen nog enige aandacht.

\subsection{Mensenrechtencompatibiliteit van het Nederlandse geschreven noodrecht}

Als het gaat om de regulering van niet-opschortbare, notstandsfeste, rechten is er een verschil in formulering tussen artikel $0_{3}$ Grondwet en artikel I5 EVRM/artikel 4 IVBPR. De Grondwet somt de bepalingen op waarvan wel kan worden afgeweken en de verdragen juist de bepalingen waarvan niet kan worden afgeweken. Dat is op zichzelf geen probleem, maar in $\$ 3.5 .4$ constateerde ik al dat artikel Io3 Grondwet afwijking van alle grondrechtenartikelen met absoluut geformuleerde procedurevoorschriften mogelijk maakt en dat daarnaast door de grondwetgever is aangegeven dat afwijking van andere grondrechtenartikelen niet nodig is, omdat de grondwettelijke beperkingsclausules slechts eisen dat de inperking van het betreffende recht, hoe vergaand die ook moge zijn, bij wet plaatsvindt of wordt geautoriseerd. Van het bieden van een onaantastbare bescherming aan de harde kern van de mensenrechtencatalogus of iets dergelijks is in de Grondwet dus eigenlijk helemaal geen sprake. Daarmee staat de grondwetstekst wel erg ver af van de gedachte die aan het concept van notstandsfeste rechten uit artikel I5 EVRM en 4 IVBPR ten grondslag ligt. Het zou dan ook verreweg de voorkeur verdienen om de constructie van artikel I03 Grondwet in lijn te brengen met die van de beide verdragsbepalingen. Dat zou dan bovendien gelegenheid bieden om ook het grondwettelijke discriminatieverbod als niet-opschortbaar aan te merken.

De Nederlandse noodwetgeving biedt ruimte voor internering (bestuurlijke detentie) van personen die als een gevaar voor de nationale veiligheid kunnen worden beschouwd (artikel I8-28 Wet bbbg, artikel 44-59 OWN). De ontwikkeling van de EHRM-jurisprudentie over artikel 5, derde en vijfde lid, en artikel I5 EVRM laat echter zien dat er ook tijdens een uitgeroepen noodtoestand geen ruimte is 
voor de toepassing van detentie van personen die beschouwd worden als gevaar voor de nationale veiligheid zonder enige rechterlijke controle en die rechterlijke controle moet binnen korte termijn na arrestatie plaatsvinden, in ieder geval niet langer dan tien dagen. De termijnen die artikel is Wet bbbg en artikel $45 \mathrm{OWN}$ geven voor een rechterlijke beoordeling van de internering zijn beduidend langer (respectievelijk een en twee maanden). Tel daarbij en het feit dat het EHRM in $A$ en anderen/VK een maatregel die het karakter had van internering van vreemdelingen die als gevaar voor de nationale veiligheid werden beschouwd beoordeelde als disproportioneel en discriminatoir en de conclusie moet mijns inziens zijn dat internering niet is te rijmen met de verdragsverplichtingen. Voor zover de door het kabinet aangekondigde verkenning van de bruikbaarheid van het staatsnoodrecht voor de bestrijding van het 'jihadisme' (zie $\S$ I.3) was ingegeven door de wens om internering toe te passen op bijvoorbeeld teruggekeerde Syriëgangers, kan daar dus een streep doorheen worden gehaald.

In de EHRM-rechtspraak wordt tevens het berechten van burgers door militaire rechtbanken of speciale rechtbanken die voor een deel uit militaire rechters bestaan consequent als strijdig met het recht op een onafhankelijk en onpartijdig tribunaal aangemerkt. Voor zover artikel I03 Grondwet ruimte laat voor afwijking van artikel II3 Grondwet om de mogelijkheid te creëren dat mobiele krijgsraden jurisdictie uitoefenen over burgers ligt er derhalve opnieuw een verdragsrechtelijke blokkade.

\subsection{Aan welke (nood)bevoegdheden is behoefte in het licht van de huidige veiligheidsbedreigingen en welke waarborgen passen daarbij?}

Het systeem van de noodwetgeving en ook het systeem van de opschortingsbepalingen uit de mensenrechtenverdragen gaan in wezen uit van een duidelijk onderscheid tussen normale situaties en noodsituaties. Nu biedt het Nederlandse geschreven noodrecht al behoorlijke flexibiliteit door de mogelijkheid van separate toepassing van noodbevoegdheden. Deze mogelijkheid tot toepassing van noodbevoegdheden buiten een noodtoestand brengt Kummeling, mijns inziens terecht, tot de conclusie dat de wettelijke optie van uitroepen van een beperkte noodtoestand in wezen geen toegevoegde waarde heeft. ${ }^{\text {I6I }}$ De zware procedure van een verklaring bij KB en vervolgens de gang naar de Verenigde Vergadering van de Staten-Generaal lijken voor dat deel van de noodbevoegdheden dat geen afwijking van grondrechten of omvangrijke inbreuken op de normale bevoegdhedentoedeling met zich brengt simpelweg te zwaar. De lichtere procedure van inwerkingstelling bij $\mathrm{KB}$ met vervolgens indiening van een verlengingswet bij de Tweede Kamer lijkt daar wel toereikend te zijn, zowel gelet op de bescherming van de burger als op de betrokkenheid van de volksvertegenwoordiging. Het uitroepen van een (algemene) uitzonderingstoestand blijft dan gereserveerd voor die gevallen dat er echt behoefte is aan de zwaarste bevoegdheden die wel die afwijking van grondrechten en inbreuk op de bevoegdhedentoedeling vergen. Bovendien kan het reserveren van uitroepen van een uitzonderingstoestand voor dat soort situaties juist bijdragen aan het daadwerkelijk gebruiken van noodrechtelijke mogelijk-

I6I Kummeling 20I4, p. 28I-282. 
heden, met de daarin voorziene procedurele waarborgen voor parlementaire betrokkenheid, in plaats van die te omzeilen en zeer ingrijpende maatregelen te treffen op een manier die de volksvertegenwoordiging veel meer buiten spel zet. Het is dan immers duidelijker dat bepaalde noodbevoegdheden ook al gebruikt mogen worden voordat het land geheel onbestuurbaar dreigt te worden.

Echter, ook bij een versterkte flexibiliteit van de inzet van noodbevoegdheden vooronderstelt toepassing van een noodrechtelijk regime nog altijd een duidelijk afgebakende dreiging waarbij er helderheid is over de noodzakelijke bevoegdheden voor het openbaar bestuur. ${ }^{162}$ Op het moment dat wordt aanvaard dat ook de dreiging van terrorisme een aantasting van een vitaal belang van de samenleving oplevert, hetgeen zowel binnen het nationale rechtstelsel als binnen de EHRMjurisprudentie het geval is, dan valt de helderheid over begin en einde van de buitengewone omstandigheden en over de noodzakelijke bevoegdheden grotendeels weg. En dat maakt de vraag of de bestrijding van deze veiligheidsbedreiging zich laat passen in het noodrechtelijke stramien van tijdelijkheid er een die lastig te beantwoorden is.

$\mathrm{Nu}$ is in het Nederlandse rechtsstelsel de tijdelijkheid van de toepassing van noodbevoegdheden wel het uitgangspunt, maar die is op minder dwingende wijze geregeld dan in sommige andere landen. Anders dan Frankrijk kennen wij geen (grond)wettelijk vastgelegde maximumduur van de uitzonderingstoestand. Het werken met wetgeving die een horizonbepaling bevat, is ons ook grotendeels onbekend.

Zou het van belang zijn om die tijdelijkheid van noodmaatregelen steviger in de noodwetgeving te verankeren, bijvoorbeeld door een wettelijke maximumduur van de uitzonderingstoestand of het frequenter gebruikmaken van horizonbepalingen in wetgeving die ziet op de bestrijding van crisissituaties of terrorisme? In 2005 toonde de Raad voor het Openbaar Bestuur zich daarvan een voorstander. ${ }^{163}$ Kummeling kwam in 2014 tot eenzelfde aanbeveling ${ }^{164}$ en het College voor de Rechten van de Mens in 2016 ook. ${ }^{165}$ Ik sluit me daarbij graag aan, maar merk wel op dat het nadrukkelijker vastleggen van de tijdelijkheid van bepaalde ingrijpende maatregelen allicht niet tot wereldschokkende veranderingen zal leiden. Het zal de wetgever dwingen tot een periodieke toetsing of de geschapen of in werking getreden bevoegdheden nog daadwerkelijk nodig zijn. De ervaring in landen die op dit punt meer ervaring hebben (VK, Frankrijk) leert echter dat de volksvertegenwoordiging niet snel een regeringsvoorstel tot verlenging van noodmaatregelen blokkeert. Zeker in de gevallen waarin de buitengewone omstandigheden bestaan uit de dreiging van terrorisme is het voor het parlement al bijna net zo moeilijk om de stellingname van het bestuur op dit punt te toetsen of te weerleggen als voor de rechter. Die stellingname zal immers doorgaans gebaseerd zijn op naar zijn aard vrijwel oncontroleerbare informatie van inlichtingendiensten.

Juist van die inlichtingendiensten wordt voor de bestrijding van terrorisme en ook de bevordering van de cybersecurity en de nauw daarmee verwante economische veiligheid veel verwacht. De roep om uitbreiding van de telecommunicatie-inter-

I62 Vgl. Raad voor het Openbaar Bestuur 2005, p. 53.

I63 Idem, p. 58.

I64 Kummeling 20I4, p. 29 I en 294.

I65 College voor de Rechten van de Mens 20r6, p. 38 . 
ceptiebevoegdheden is sterk. ${ }^{166}$ De groep burgers die daardoor geconfronteerd zal worden met een inbreuk op het telecommunicatiegeheim is omvangrijk. Het gaat dus om ingrijpende bevoegdheden die bij voorkeur inderdaad alleen kortdurend en bij ernstige veiligheidsbedreigingen zouden moeten worden ingezet. Het gaat echter wel om bevoegdheden die in het geheim worden uitgeoefend waardoor het toepassen van noodrechtelijke principes als publieke afkondiging en verlenging door de wetgever moeilijk is en waarschijnlijk ook niet veel extra bescherming van de in het geding zijnde mensenrechten oplevert. Ik verwacht daar dan meer heil van een zwaar opgetuigd onafhankelijk toezicht door een instantie die bindende beslissingen kan nemen over de voortzetting van interceptieoperaties. De EHRM-jurisprudentie dwingt daar ook toe. ${ }^{167}$

Ook waar het gaat om andere bestuurlijke maatregelen in de sfeer van de terrorismebestrijding die momenteel worden getroffen of in het parlement bediscussieerd worden, ben ik geneigd om meer te verwachten van een versterkte rechterlijke toets, bij voorkeur voorafgaand aan de toepassing van de maatregel, dan inpassing in het noodrechtelijke stramien van tijdelijkheid. Weliswaar zijn ook de beginselen van proportionaliteit en subsidiariteit belangrijke noodrechtelijke principes - deze zouden best expliciet gecodificeerd mogen worden in het noodrecht, bijvoorbeeld in artikel ${ }_{103}$ Grondwet $^{168}$ of in de Cwu - maar de rechter is doorgaans beter in staat tot een toetsing aan deze principes dan de volksvertegenwoordiging.

\subsection{Onduidelijkheid over grens tussen beperking en opschorting van mensenrechten}

De verdragsrechtelijke eisen waaraan toepassing van noodmaatregelen moet voldoen zoals die werden opgesomd in $\$$ 5.I zijn alleen relevant voor zover die noodmaatregelen een opschorting van mensenrechten inhouden. En in $\$ 3.5 .4$ gaf ik al aan dat de grondwettelijke systematiek voor afwijking van grondrechten ervan uitgaat dat bij alle rechten die niet in het lijstje van artikel I03 staan een eventuele vergaande noodwettelijke beperking reeds is toegestaan op basis van de gewone grondwettelijke beperkingsclausules die de wetgever grotendeels de vrije hand laten.

Waar ligt nu precies de grens tussen de gewone inperking en de opschorting van een grondrecht? De Grondwet biedt voor het antwoord op deze vraag geen aanknopingspunten en ook de EHRM-jurisprudentie biedt die nauwelijks. Alleen bij het recht op onverwijlde voorgeleiding van in verzekering gestelde verdachten (artikel 5, derde lid, EVRM) is daarover iets af te leiden uit de Straatsburgse rechtspraak (zie $\$ 5.2$ hierboven). Met name bij rechten die voorzien zijn van een eigen beperkingsclausule is niet helder voor welk type van inbreuken nu per se een beroep op de opschortingsmogelijkheid noodzakelijk is. De Franse regering meldde in november 2015 aan de secretaris-generaal van de Raad van Europa dat het uitroepen van de noodtoestand maatregelen in zou kunnen houden die afweken van de

I66 Zie Commissie-Dessens, Evaluatie Wet op de Inlichtingen- en veiligheidsdiensten 2002, Naar een nieuwe balans tussen bevoegdheden en waarborgen, Den Haag 2013, hoofdstuk 5 .

I67 Zie Loof, Uzman e.a. 2015, p. I8-I9 en 39.

I68 Kummeling 20I4, p. 293-294 en 297, doet daartoe een tekstvoorstel. 
verplichtingen onder het EVRM. Om welke EVRM-artikelen het dan zou gaan werd niet aangegeven, maar allicht was de gedachte dat bijvoorbeeld het toepassen van huiszoekingen zonder voorafgaande rechterlijke machtiging niet te verenigen is met de bescherming die artikel 8 EVRM geeft aan de persoonlijke levenssfeer. Of zulke huiszoekingen echter eventueel ook gerechtvaardigd zouden kunnen worden onder de noodzakelijkheids- en proportionaliteitstoets van artikel 8, tweede lid, valt niet met zekerheid te zeggen. Ik zou menen van niet, maar er zijn simpelweg geen Straatsburgse precedenten die volledige duidelijkheid bieden.

Gezien de manier waarop de Straatsburgse proprtionaliteitstoets onder artikel I5 EVRM zich ontwikkelt (zie \$ 5.4 hierboven), durf ik met enige voorzichtigheid de stelling zelfs aan dat die uiteindelijk helemaal niet zoveel verschilt van die onder artikel 8, tweede lid. Een beroep op de opschortingsbepalingen is dan eigenlijk slechts echt relevant (vanuit het perspectief van de staat) waar het gaat om rechten die geen eigen beperkingsclausule kennen. In $\$ 5.3$ heb ik al getracht duidelijk te maken dat die rechten (onder meer het recht op leven, het verbod van foltering en onmenselijke behandeling, maar ook het recht van habeas corpus en het recht op een eerlijk proces), voor een belangrijk deel niet-opschortbaar zijn.

\subsection{Codificatie van het subjectieve noodrecht?}

Nee, het huidige geschreven noodrecht sluit niet goed aan op de veiligheidsbedreigingen waar Nederland anno 2016 mee te maken heeft. Maar de maatregelen die nodig zijn om aan die bedreigingen het hoofd te bieden laten zich ook lang niet allemaal voegen in een noodrechtelijk stramien. Met name waar het gaat om antiterrorismemaatregelen is moeilijk aan te geven vanaf welk moment de terrorismedreiging zodanig is dat bevoegdheden wel of juist niet langer nodig zijn.

Zou het dan belangrijk kunnen zijn om grondwettelijk te erkennen dat in bepaalde crisissituaties kan worden afgeweken van de wetgeving, inclusief de specifieke noodwetgeving? Kummeling toonde zich in 2014 voorstander van wat in wezen neerkomt op een codificatie van het subjectieve staatsnoodrecht. Kortmann zag al eerder geen principiële bezwaren hiertegen, al vreesde hij dat codificatie al snel te starre formuleringen zou kunnen inhouden. ${ }^{\mathrm{I} 9}{ }^{\mathrm{Bij}}$ de grondwetsherziening van 1983 gaf de regering nog aan dat juist het niet-codificeren van dit noodrecht de beste waarborg zou vormen om onnodig gebruik ervan te voorkomen. Of dat zo is, kan worden betwist. Beslissend zou denk ik moeten zijn of bij codificatie randvoorwaarden voor de uitoefening van het noodrecht kunnen worden geformuleerd die nu niet zo expliciet zijn. Een volledig open bevoegdheidstoekenning heeft geen toegevoegde waarde. Codificatie zou echter wel een mogelijkheid bieden om een randvoorwaarde à la het 'strikt vereist'-criterium uit artikel I5 EVRM/ artikel 4 IVBPR (dus een subsidiariteits- en proportionaliteitseis) grondwettelijk te expliciteren. Het vastleggen daarvan in de Grondwet zou denk ik het voordeel hebben dat het daarmee een duidelijk door onze eigen volksvertegenwoordiging vastgelegd vereiste wordt en niet één dat voortvloeit uit verdragsverplichtingen. Zeker nu de bestuurders die de noodbevoegdheid moeten toepassen niet altijd zoveel op hebben met verdragsverplichtingen die voortvloeien uit 'achterhaalde verdragen'

I69 Kortmann I984, p. I84-I86. 
die bovendien worden uitgelegd door 'niet democratisch gelegitimeerde' internationale of Europese rechters verdient het aanbeveling om zo'n randvoorwaarde expliciet in ons eigen rechtsstelsel te internaliseren.

En als er dan toch gecodificeerd wordt, kan allicht gelijk het Statuut voor het Koninkrijk worden geactualiseerd. Want dat loopt met zijn verwijzing naar niet meer bestaande noodtoestanden wel heel erg ver achter de feiten aan. 